\title{
Serendipitous compositional and structural diversity in urotropine adducts of binary cadmium xanthates
}

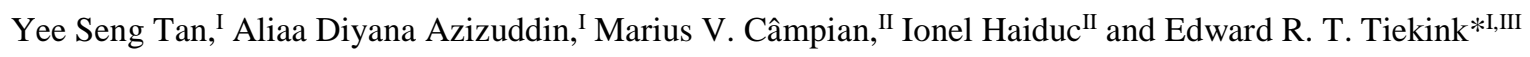 \\ ${ }^{\text {I }}$ University of Malaya, Department of Chemistry, 50603 Kuala Lumpur, Malaysia \\ II Babes-Bolyai University, Department of Chemistry, RO-400028, Cluj-Napoca, Romania \\ III Sunway University, Centre for Chemical Crystallography, Faculty of Science and Technology, 47500 Bandar Sunway, Selangor Darul \\ Ehsan, Malaysia
}

Received; accepted

Keywords: Xanthate / cadmium / urotropine / crystal structure analysis / X-ray diffraction

\begin{abstract}
Three new compounds, $\mathrm{Cd}\left(\mathrm{S}_{2} \mathrm{COMe}\right)_{2}(\mathrm{hmta})(\mathbf{1})$, $\mathrm{Cd}\left(\mathrm{S}_{2} \mathrm{COEt}\right)_{2}(\mathrm{hmta})_{0.5}$ (2) and $\mathrm{Cd}\left(\mathrm{S}_{2} \mathrm{COiPr}\right)_{2}$ (hmta) (3), have been isolated from a systematic study of adduct formation between $\mathrm{Cd}\left(\mathrm{S}_{2} \mathrm{COR}\right)_{2}, \mathrm{R}=\mathrm{Me}$, Et and $\mathrm{iPr}$, precursors and potentially polydentate hmta; hmta is urotropine (hexamethylenetetramine). The compounds have been characterised by a variety of spectroscopic techniques including a photoluminescence study in both solution and the solid-state, as well as by thermal methods. Crystallography shows 1 to have $\mu_{2-}$ bridging hmta leading to a one-dimensional coordination polymer. This framework is essentially repeated in $\mathbf{2}$ but with a $\mu_{3}$-bridging hmta so that $\mathrm{Cd}\left(\mathrm{S}_{2} \mathrm{COEt}\right)_{2}$ entities decorate the chain. By contrast, a binuclear zero-dimensional aggregate with terminally bound hmta is found in $\mathbf{3}$. The influence of steric bulk of the alkyl substituents in $\mathrm{Cd}\left(\mathrm{S}_{2} \mathrm{COR}\right)_{2}$ is pivotal in determining the ultimate structural outcome.
\end{abstract}

* Correspondence author: edwardt@ sunway.edu.my (E.R.T.T.)

\section{Introduction}

Dithiocarbonates (xanthates), dithiocarbamates and dithiophosphates are important members of the 1,1-dithiolate class of compounds, Fig. 1 [1-7]. Being easy to prepare and having a great propensity for complexing heavy elements ranging from the transition metals, lanthanides, and relevant to

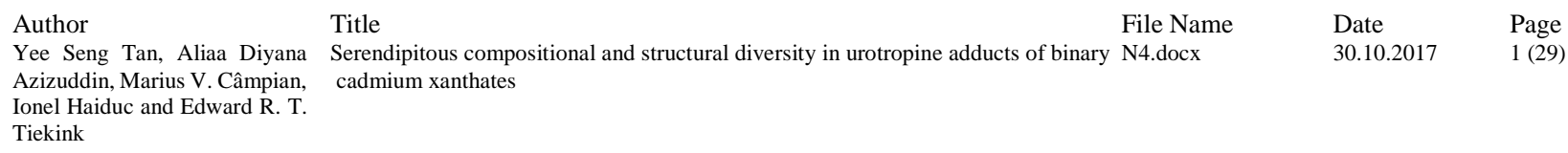


the present study, main group elements, it is not surprising that there is an enormous wealth of structural data for metal 1,1-dithiolates [1-7]. Amongst these, the structural chemistry exhibited by the binary cadmium xanthates, $\mathrm{Cd}\left(\mathrm{S}_{2} \mathrm{COR}\right)_{2}$ is remarkable for its diversity and complexity [1].<smiles>[R]OC(=S)[S-]</smiles>

(a)<smiles>[R7][O+]=C([S-])[S-]</smiles>

(d)<smiles>[R6]P([O-])(=S)[S-]</smiles>

(c)

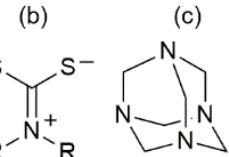

(e)

Fig. 1. Generic chemical structures for the (a) xanthate, (b) dithiocarbamate and (c) dithiophosphate anions. Resonance structures for the (d) xanthate and (e) dithiocarbamate anions. (f) Chemical structure of urotropine (hmta).

As seen from Fig. 2, three quite distinct structural motifs are observed for these compounds, ranging from zero-dimensional in the case of the mononuclear compound found for $\mathrm{R}=\mathrm{CH}_{2} \mathrm{CH}_{2} \mathrm{OMe}$ [8], one-dimensional in the form of a supramolecular chain when $\mathrm{R}=\mathrm{Me}$ [9], and two-dimensional, as extended sheets, when $\mathrm{R}=\mathrm{Et}$, $\mathrm{iPr}$ and $\mathrm{n}-\mathrm{Bu}[10$ $15]$.

(a)<smiles>CCC1CC2CC(CC)C2C1</smiles>

(b)

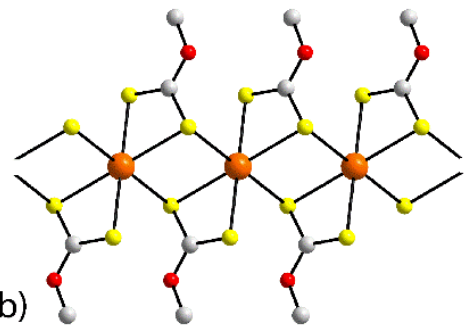

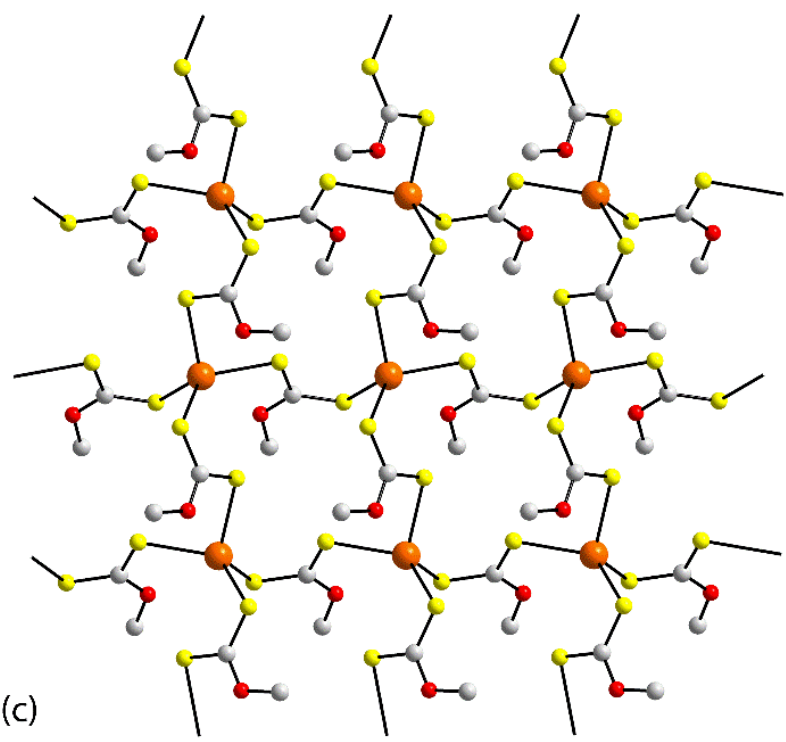

Fig. 2. The three different structural motifs adopted by binary cadmium xanthates (a) zero-dimensional, mononuclear found for $\mathrm{R}=\mathrm{CH}_{2} \mathrm{CH}_{2} \mathrm{OMe}$, (b) one-dimensional supramolecular chain found for $\mathrm{R}=\mathrm{Me}$, and (c) two-dimensional su- 
pramolecular layer found for $\mathrm{R}=\mathrm{Et}$, i-Pr and $\mathrm{n}-\mathrm{Bu}$. All hydrogen atoms and all but the alpha-carbon atoms bound to oxygen have been omitted.

Contrasting the behaviour of the cadmium xanthates is the structural chemistry of the binary cadmium dithiocarbamates, $\mathrm{Cd}\left(\mathrm{S}_{2} \mathrm{CNR}_{2}\right)_{2}$, which normally features a binuclear, zero-dimensional aggregate as a result of two chelating ligands and two ligands which simultaneously chelate one cadmium centre while bridging another, i.e. $\mu_{2} \kappa^{2}$-tridentate [1634]. This dramatic difference in structural outcomes is rationalised in terms of the significant contribution of the canonical structure shown in Fig. 1e, up to $40 \%$, which makes dithiocarbamate ligands effective chelating agents certainly compared with the xanthate ligand where the equivalent canonical structure, Fig. 1d, contributes no more than $20 \%$ to the overall electronic structure of the anion [1]. The above notwithstanding, the relatively "staid" coordination chemistry for $\mathrm{Cd}\left(\mathrm{S}_{2} \mathrm{CNR}_{2}\right)_{2}$ has been challenged recently by the characterisation of supramolecular isomers [35, 35] of the one-dimensional coordination polymers, $\left[\left\{\mathrm{Cd}\left[\mathrm{S}_{2} \mathrm{CN}(\mathrm{iPr}) \mathrm{CH}_{2} \mathrm{CH}_{2} \mathrm{OH}\right]_{2}\right\}_{3} \cdot \mathrm{MeCN}\right]_{\infty} \quad$ [37] and $\left[\left\{\mathrm{Cd}\left[\mathrm{S}_{2} \mathrm{CN}(\mathrm{iPr}) \mathrm{CH}_{2} \mathrm{CH}_{2} \mathrm{OH}\right]_{2}\right\}_{3} \cdot 2 \mathrm{EtOH}\right]_{\infty}$ [38] for which all dithiocarbamate ligands are $\mu_{2} \kappa^{2}$-tridentate. Further, a zerodimensional trinuclear aggregate has been isolated recently, $\left\{\mathrm{Cd}\left[\mathrm{S}_{2} \mathrm{CN} \text { (methylbenzyl)(methylfurfuryl) }\right]_{2}\right\}_{3}$, where the ratio of $\mu_{2} \kappa^{2}$-tridentate to chelating ligands is $2: 1$ leading to a central octahedrally coordinated cadmium flanked by two square pyramidal cadmium atoms [39]. The structural chemistry of the binary cadmium dithiophosphates resembles that of $\mathrm{Cd}\left(\mathrm{S}_{2} \mathrm{CNR}_{2}\right)_{2}$ in that both zero- (binuclear) [40-42] and one-dimensional [43-45] aggregation patterns are observed.

While the mainstay of the construction of coordination polymers of metal carboxylates has been to incorporate neutral and multidentate pyridine-donor ligands of which 4,4'bipyridine (4,4'-bipy) is a prominent exemplar, the analogous chemistry of 1,1-dithiolates is far less developed. In fact, there is only one example of structurally characterised cadmium xanthate with bridging bipyridine-type ligands, namely $\left[\mathrm{Cd}\left(\mathrm{S}_{2} \mathrm{COiPr}\right)_{2}\left(4,4^{\prime}-\text {-bipy }\right)\right]_{\mathrm{n}}$, which is a linear polymer [46], even though structures with bidentate bipyridine donors are well known [47-49]. A linear coordination polymer is also noted in the structure of $\left\{\mathrm{Cd}\left[\mathrm{S}_{2} \mathrm{CN}\left(\mathrm{CH}_{2} \mathrm{Ph}\right)_{2}\right]_{2}(4,4 \text { '-bipy })\right\}_{\mathrm{n}}$ [50]. This structure is complemented by highly flattened zig-zag polymers in each of $\left\{\mathrm{Cd}\left(\mathrm{S}_{2} \mathrm{CNEt}_{2}\right)_{2} \text { [1,2-bis(4-pyridyl)ethane] }\right\}_{\mathrm{n}} \quad$ [51] and $\left\{\mathrm{Cd}\left(\mathrm{S}_{2} \mathrm{CNEt}_{2}\right)_{2} \text { [1,2-bis(4-pyridyl)ethylene] }\right\}_{\mathrm{n}}$ [52]. By contrast to the aforementioned, the chemistry of cadmium dithiophosphates with bridging bipyridine-type ligands is far more developed [53-58], with 17 different structures found in the Cambridge Structural Database [59]. A systematic study focussed on the influence of the steric profile of the remote organic substituents upon coordination polymer formation and, when polymers were formed, their topology [5355]. The controlling influence of steric bulk in influencing supramolecular aggregation patterns, in particular in militating secondary interactions $[60,61]$, in main group 1,1-dithiolate chemistry is now well established [62-66]. It is noted that in none of the cadmium structures with bridging bipyridine-type ligands were the 1,1-dithiolate ligands bridging so

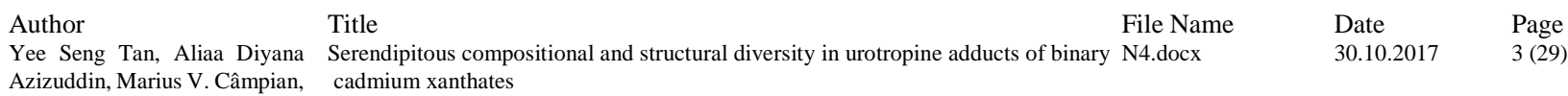

Ionel Haiduc and Edward R. T.

Tiekink 
that only one-dimensional architectures were formed. In an attempt to increase the dimensionality of the ensuing coordination polymer, attention was directed to the potentially polydentate ligand urotropine (hexamethylenetetramine, hereafter hmta), Fig. 1f.

The utility of hmta in the construction of coordination polymers has been reviewed recently which summarised a variety of "inverse coordination modes", i.e. where hmta is regarded as the coordination centre [67]. Bridging, i.e. $\mu_{2^{-}}$, $\mu_{3}$ - and even $\mu_{4}$-hmta, predominates with terminal coordination of hmta observed in less than $5 \%$ of the discussed coordination polymers (excluding those containing silver) [67]. With this background in mind, an exploration of adduct formation between each of $\mathrm{Cd}\left(\mathrm{S}_{2} \mathrm{COR}\right)_{2}, \mathrm{R}=\mathrm{Me}$, Et and $\mathrm{iPr}$, and hmta is described in which the ratio of $\mathrm{Cd}\left(\mathrm{S}_{2} \mathrm{COR}\right)_{2}$ to hmta was varied from 1:1, 2:1 and 1:2, was undertaken. Remarkably, from the nine possible products only three compounds could be prepared, namely $\mathrm{Cd}\left(\mathrm{S}_{2} \mathrm{COMe}\right)_{2}(\mathrm{hmta})(\mathbf{1})$, $\mathrm{Cd}\left(\mathrm{S}_{2} \mathrm{COEt}\right)_{2}(\mathrm{hmta})_{0.5}$ (2) and $\mathrm{Cd}\left(\mathrm{S}_{2} \mathrm{COiPr}\right)_{2}(\mathrm{hmta})(\mathbf{3})$, i.e. each with a different composition. Even more remarkably, the crystallographically determined structures of 1-3 are quite different owing to the different coordination modes of hmta, i.e. monodentate, $\mu_{2}$-bidentate and $\mu_{3}$-tridentate so that different architectures are generated. The results of this investigation are reported herein.

\section{Experimental}

\section{Instrumentation}

All chemicals and solvents were used as purchased without purification and reactions were carried out under ambient conditions. Elemental analyses were performed on a Perkin Elmer PE $2400 \mathrm{CHN}$ Elemental Analyser. ${ }^{1} \mathrm{H}$ and ${ }^{13} \mathrm{C}\left\{{ }^{1} \mathrm{H}\right\}$ NMR spectra were recorded in DMSO- $\mathrm{d}_{6}$ solutions on a Bruker Avance $400 \mathrm{MHz}$ NMR spectrometer with chemical shifts relative to tetramethylsilane; abbreviations for NMR assignments: s, singlet; d, doublet; t, triplet; q, quartet; sept, septet. IR spectra were measured on a Perkin Elmer Spectrum 400 FT Mid-IR/Far-IR spectrophotometer from 4000 to $400 \mathrm{~cm}^{-1}$; abbreviations: vs, very strong; s, strong; m, medium; w, weak. The optical absorption spectra were measured on 10 and $100 \mu \mathrm{M}$ ethanol:acetonitrile (1:1) solutions in the range 190-1100 nm on a single-beam Agilent Cary 60 UV-Vis spectrophotometer. Photoluminescence (PL) measurements were carried out at room temperature on $1 \mathrm{mM}$ in acetonitrile:ethanol (1:1) solutions using an Agilent Varian Cary Eclipse Fluorescence Spectrophotometer with a Xenon flash lamp as the excitation source. Solid-state PL measurements were carried out using the same instrument. Solid samples were loaded on a SH1 plain sample holder of an Optistat DN2 (Oxford Instrument Nanoscience) attachment; liquid nitrogen was loaded into the cryostat system for low temperature $(77 \mathrm{~K})$ measurements. Thermogravimetric analyses were performed on a Perkin Elmer TGA 4000 Thermogravimetric Analyzer in the range of $35-900{ }^{\circ} \mathrm{C}$ at the rate of 10 ${ }^{\circ} \mathrm{C} / \mathrm{min}$. 


\section{Synthesis and characterization}

\section{Preparation of xanthate salts}

The potassium salts of the three xanthate ligands, $\mathrm{K}\left[\mathrm{S}_{2} \mathrm{COR}\right]$ for $\mathrm{R}=\mathrm{Me}$, Et and iPr, were prepared by dissolving $\mathrm{KOH}$ (ca $0.05 \mathrm{~mol}$ ) in an excess of the respective alcohol followed by the slow addition of an equivalent amount of $\mathrm{CS}_{2}$. The precipitate which immediately formed was filtered off, dried in vacuo at room temperature and used as prepared.

\section{Synthesis of binary cadmium xanthates}

The same method was employed for the preparation of each of $\mathrm{Cd}\left(\mathrm{S}_{2} \mathrm{COR}\right)_{2}$ for $\mathrm{R}=\mathrm{Me}$, Et and iPr. An aqueous solution (25 ml) of $\mathrm{CdCl}_{2}$ (99.0\% purity; Acros Organic; $2.75 \mathrm{~g}$ ) was added to 2 molar equivalents of the respective xanthate taken up in ethanol $(\mathrm{R}=\mathrm{Me}: 25 \mathrm{ml})$ or water $(\mathrm{R}=\mathrm{Et}$, iPr: $25 \mathrm{ml})$. The resulting mixture was stirred for $1 \mathrm{~h}$ and the precipitate that formed was suction filtered and air-dried. The products were characterised spectroscopically and used for subsequent reaction with hmta (Acros Organic).

$\mathrm{Cd}\left(\mathrm{S}_{2} \mathrm{COMe}\right)_{2}$ : Yield $4.26 \mathrm{~g}(87 \%)$ as pale-yellow needles. ${ }^{1} \mathrm{H}$ NMR (DMSO- $\left.d_{6}, 25^{\circ} \mathrm{C}\right): \delta 3.95\left(s, 3 \mathrm{H}, \mathrm{OCH}_{3}\right) \mathrm{ppm}$. ${ }^{13} \mathrm{C}\left\{{ }^{1} \mathrm{H}\right\}$ NMR (DMSO- $\left.d_{6}, 25^{\circ} \mathrm{C}\right): \delta 230.1\left(\mathrm{C}_{\mathrm{q}}\right), 62.7\left(\mathrm{OCH}_{3}\right)$ ppm. IR (cm $\left.{ }^{-1}\right): 1218$ (vs) v(C-O), 1029 (vs) v(C-S).

$\mathrm{Cd}\left(\mathrm{S}_{2} \mathrm{COEt}\right)_{2}$ : Yield $4.74 \mathrm{~g}(89 \%)$ as a milky-white powder. ${ }^{1} \mathrm{H}$ NMR (DMSO- $\left.d_{6}, 25{ }^{\circ} \mathrm{C}\right): \delta 4.34\left(q, 2 \mathrm{H}, \mathrm{OCH}_{2}, \mathrm{~J}=7.07\right.$ $\mathrm{Hz}), 1.30\left(t, 3 \mathrm{H}, \mathrm{CH}_{3}, \mathrm{~J}=7.08 \mathrm{~Hz}\right) \mathrm{ppm} .{ }^{13} \mathrm{C}\left\{{ }^{1} \mathrm{H}\right\} \mathrm{NMR}$ (DMSO- $\left.d_{6}, 25{ }^{\circ} \mathrm{C}\right): \delta 229.2\left(\mathrm{C}_{\mathrm{q}}\right), 72.3\left(\mathrm{OCH}_{2}\right), 14.0\left(\mathrm{CH}_{3}\right)$ ppm. IR (cm $\left.{ }^{-1}\right)$ : 1195 (vs) v(C-O), 1029 (vs) v(C-S).

$\mathrm{Cd}\left(\mathrm{S}_{2} \mathrm{COiPr}\right)_{2}$ : Yield: $4.48 \mathrm{~g}(78 \%)$ as a yellow powder. ${ }^{1} \mathrm{H}$ NMR (DMSO- $\left.d_{6}, 25^{\circ} \mathrm{C}\right): \delta 5.12($ sept $, 1 \mathrm{H}, \mathrm{OCH}, \mathrm{J}=6.17$ $\mathrm{Hz}), 1.30\left(t, 6 \mathrm{H}, \mathrm{CH}_{3}, \mathrm{~J}=6.20 \mathrm{~Hz}\right) \mathrm{ppm} .{ }^{13} \mathrm{C}\left\{{ }^{1} \mathrm{H}\right\} \mathrm{NMR}$ (DMSO- $\left.d_{6}, 25^{\circ} \mathrm{C}\right): \delta 228.2\left(\mathrm{C}_{\mathrm{q}}\right), 80.4(\mathrm{OCH}), 21.3\left(\mathrm{CH}_{3}\right)$ ppm. IR (cm $\left.{ }^{-1}\right)$ : 1202 (vs) v(C-O), 1021 (vs) v(C-S).

hmta: ${ }^{1} \mathrm{H}$ NMR (DMSO-d $\left.6,25^{\circ} \mathrm{C}\right): \delta 4.52\left(s, 12 \mathrm{H}, \mathrm{CH}_{2}\right) \mathrm{ppm}$. ${ }^{13} \mathrm{C}\left\{{ }^{1} \mathrm{H}\right\}$ NMR (DMSO- $\left.d_{6}, 25^{\circ} \mathrm{C}\right): \delta 73.8\left(\mathrm{CH}_{2}\right) \mathrm{ppm}$. IR $\left(\mathrm{cm}^{-1}\right): 1456(\mathrm{~m}) v_{\mathrm{as}}(\mathrm{C}-\mathrm{H}), 1369(\mathrm{~s}) v_{\mathrm{s}}(\mathrm{C}-\mathrm{H}), 1234(\mathrm{vs}) v(\mathrm{C}-$ $\mathrm{N})$.

Synthesis of $\mathrm{Cd}\left(\mathrm{S}_{2} \mathrm{COR}\right)_{2}(\mathrm{hmta})_{\mathrm{n}}$ adducts, $\mathrm{R}=\mathrm{Me}(1), \mathrm{Et}$ (2) and iPr (3)

The methods employed for the preparation of the hmta adducts were similar and hence, only details for the experiments involving the $\mathrm{R}=\mathrm{Me}$ precursor will be given. In separate experiments, to a suspension of $\mathrm{Cd}\left(\mathrm{S}_{2} \mathrm{COMe}\right)_{2}(0.65 \mathrm{~g})$ in ethanol $(25 \mathrm{ml})$ was added $0.5,1.0$ and 2.0 molar equivalents of hmta in ethanol $(25 \mathrm{ml})$. The resulting mixtures were stirred for $1 \mathrm{~h}$ at $50^{\circ} \mathrm{C}$ on a hot-plate. After cooling to room temperature, the solution was filtered and the filtrate left for slow evaporation, yielding crystals typically after 3 days. The crystals obtained from each reaction were screened by PXRD. From the nine experiments, three new compounds were isolated.

$\mathrm{Cd}\left(\mathrm{S}_{2} \mathrm{COMe}\right)_{2}$ (hmta) (1). Yield: $0.51 \mathrm{~g}(55 \%)$ as colourless crystals. Anal. Calc. for $\mathrm{C}_{10} \mathrm{H}_{18} \mathrm{CdN}_{4} \mathrm{O}_{2} \mathrm{~S}_{4}$ : C, 25.72; H, 3.89; N, 12.00. Found: C, 25.44; H, 3.87; N, 11.69. ${ }^{1} \mathrm{H}$ NMR $\left(\mathrm{DMSO}_{6}, 25^{\circ} \mathrm{C}\right): \delta 4.60\left(s, 12 \mathrm{H}, \mathrm{CH}_{2}\right), 3.95\left(s, 6 \mathrm{H}, \mathrm{OCH}_{3}\right)$ ppm. ${ }^{13} \mathrm{C}\left\{{ }^{1} \mathrm{H}\right\}$ NMR (DMSO-d $\left.6,25{ }^{\circ} \mathrm{C}\right): \delta 230.0\left(\mathrm{C}_{\mathrm{q}}\right), 73.4$ $\left(\mathrm{CH}_{2}\right), 62.6\left(\mathrm{OCH}_{3}\right)$ ppm. IR $\left(\mathrm{cm}^{-1}\right): 1460(\mathrm{~m}) v_{\mathrm{as}}(\mathrm{C}-\mathrm{H})$, 
$1375(\mathrm{w}) v_{\mathrm{s}}(\mathrm{C}-\mathrm{H}), 1238(\mathrm{~s}) v(\mathrm{C}-\mathrm{N}), 1200(\mathrm{vs}) v(\mathrm{C}-\mathrm{O}), 1016$

(vs) $v(\mathrm{C}-\mathrm{S})$.

$\mathrm{Cd}\left(\mathrm{S}_{2} \mathrm{COEt}\right)_{2}(\mathrm{hmta})_{0.5}(2)$. Yield: $1.26 \mathrm{~g}(74 \%)$ as pale-yellow crystals. Anal. Calc. for $\mathrm{C}_{18} \mathrm{H}_{32} \mathrm{Cd}_{2} \mathrm{~N}_{4} \mathrm{O}_{4} \mathrm{~S}_{8}: \mathrm{C}, 25.44 ; \mathrm{H}$, 3.80; N, 6.59. Found: C, 25.12; H, 3.70; N, 6.54. ${ }^{1} \mathrm{H}$ NMR (DMSO- $\left.\mathrm{d}_{6}, 25^{\circ} \mathrm{C}\right): \delta 4.58\left(s, 12 \mathrm{H}, \mathrm{CH}_{2}\right), 4.34\left(q, 8 \mathrm{H}, \mathrm{OCH}_{2}\right.$, $\mathrm{J}=7.05 \mathrm{~Hz}), 1.30\left(t, 12 \mathrm{H}, \mathrm{CH}_{3}, \mathrm{~J}=7.06 \mathrm{~Hz}\right) \mathrm{ppm} .{ }^{13} \mathrm{C}\left\{{ }^{1} \mathrm{H}\right\}$ NMR (DMSO-d $\left.6,25{ }^{\circ} \mathrm{C}\right): \delta 229.2\left(\mathrm{C}_{\mathrm{q}}\right), 73.7\left(\mathrm{CH}_{2}\right), 72.3$ $\left(\mathrm{OCH}_{2}\right), 14.0\left(\mathrm{CH}_{3}\right) \mathrm{ppm}$. IR $\left(\mathrm{cm}^{-1}\right): 1461(\mathrm{~m}) v_{\text {as }}(\mathrm{C}-\mathrm{H})$, 1365 (w) $v_{\mathrm{s}}(\mathrm{C}-\mathrm{H}), 1232$ (m) $v(\mathrm{C}-\mathrm{N}), 1197$ (vs) $v(\mathrm{C}-\mathrm{O})$, 1014 (vs) v(C-S).

$\mathrm{Cd}\left(\mathrm{S}_{2} \mathrm{COiPr}\right)_{2}(\mathrm{hmta})$ (3). Yield: $0.81 \mathrm{~g}(77 \%)$ as pale-yellow crystals. Anal. Calc. for $\mathrm{C}_{28} \mathrm{H}_{52} \mathrm{Cd}_{2} \mathrm{~N}_{8} \mathrm{O}_{4} \mathrm{~S}_{8}: \mathrm{C}, 32.15 ; \mathrm{H}$, 5.01; N, 10.71. Found: C, 31.97; H, 5.07; N, 10.49. ${ }^{1} \mathrm{H}$ NMR (DMSO- $\mathrm{d}_{6}, 25^{\circ} \mathrm{C}$ ): $\delta 5.13($ sept, $2 \mathrm{H}, \mathrm{OCH}, \mathrm{J}=6.17 \mathrm{~Hz}), 4.58$ $\left(s, 12 \mathrm{H}, \mathrm{CH}_{2}\right), 1.30\left(t, 12 \mathrm{H}, \mathrm{CH}_{3}, \mathrm{~J}=6.20 \mathrm{~Hz}\right) \mathrm{ppm} .{ }^{13} \mathrm{C}\left\{{ }^{1} \mathrm{H}\right\}$ NMR (DMSO- $\left.\mathrm{d}_{6}, 25^{\circ} \mathrm{C}\right): \delta 228.3\left(\mathrm{C}_{\mathrm{q}}\right), 80.6(\mathrm{OCH}), 73.7$ $\left(\mathrm{CH}_{2}\right), 21.3\left(\mathrm{CH}_{3}\right) \mathrm{ppm}$. IR $\left(\mathrm{cm}^{-1}\right): 1459(\mathrm{~m}) \mathrm{v}_{\mathrm{as}}(\mathrm{C}-\mathrm{H}), 1370$ (w) $v_{\mathrm{s}}(\mathrm{C}-\mathrm{H}), 1246(\mathrm{~s}) v(\mathrm{C}-\mathrm{N}), 1206(\mathrm{vs}) v(\mathrm{C}-\mathrm{O}), 1013(\mathrm{vs})$ $v(\mathrm{C}-\mathrm{S})$.

\section{Crystal structure determination}

A Rigaku AFC12א/SATURN724 diffractometer fitted with Mo $K \alpha$ radiation $(\lambda=0.71073 \AA$ ) was employed to measure intensity data for 1 at $98 \mathrm{~K}$. Data processing and absorption corrections were accomplished with CrystalClear [68] and ABSCOR [69], respectively. Intensity data for $\mathbf{2}$ and $\mathbf{3}$ were measured at $100 \mathrm{~K}$ on an Agilent Technologies SuperNova Dual CCD with an Atlas detector also fitted with Mo K $\alpha$ radiation. Data processing and absorption correction were accomplished with CrysAlis PRO [70]. With the use of SHELXS-97 [71] and SHELXL-2014/7 [72] programs integrated into WinGX [73], the structures were solved by direct methods and refined on $F^{2}$ by full-matrix least-squares with anisotropic displacement parameters for all non-hydrogen atoms. The C-bound $\mathrm{H}$ atoms were placed on stereochemical grounds and refined in the riding model approximation with $U_{\text {iso }}=1.2-1.5 U_{\text {eq }}$ (carrier atom). A weighting scheme of the form $w=1 /\left[\sigma^{2}\left(F_{\mathrm{o}}{ }^{2}\right)+(a P)^{2}+b P\right]$ where $P=\left(F_{\mathrm{o}}{ }^{2}+2 F_{\mathrm{c}}{ }^{2}\right) / 3$ was introduced in each case. For $\mathbf{3}$, owing to poor agreement, perhaps due to the effect of the beam-stop, two low angle reflections, i.e. ( $\left(\begin{array}{lll}1 & 0 & 0\end{array}\right)$ and $\left(\begin{array}{lll}0 & 1 & 0\end{array}\right)$, were omitted from the final refinement. Generally, relatively high motion was observed for the terminal methyl groups and in particular for C4. However, multiple sites could not be resolved in this low temperature $(100 \mathrm{~K})$ study. This was despite the observation that the maximum residual electron density peaks were located in this region of the structures, i.e. the maximum and minimum residual electron density peaks of 1.20 and $1.00 \AA^{-3}$, respectively, were located 0.48 and $0.44 \AA$ from the $\mathrm{H} 4 \mathrm{a}$ and $\mathrm{C} 4$ atoms, respectively. Unit cell data, Xray data collection parameters, and details of the structure refinement are given in Table 1. The programs ORTEP-3 for Windows [73], PLATON [74] and DIAMOND [75] were also used in the analysis. 
Table 1. Crystallographic data and refinement details for 1-3. ${ }^{l}$

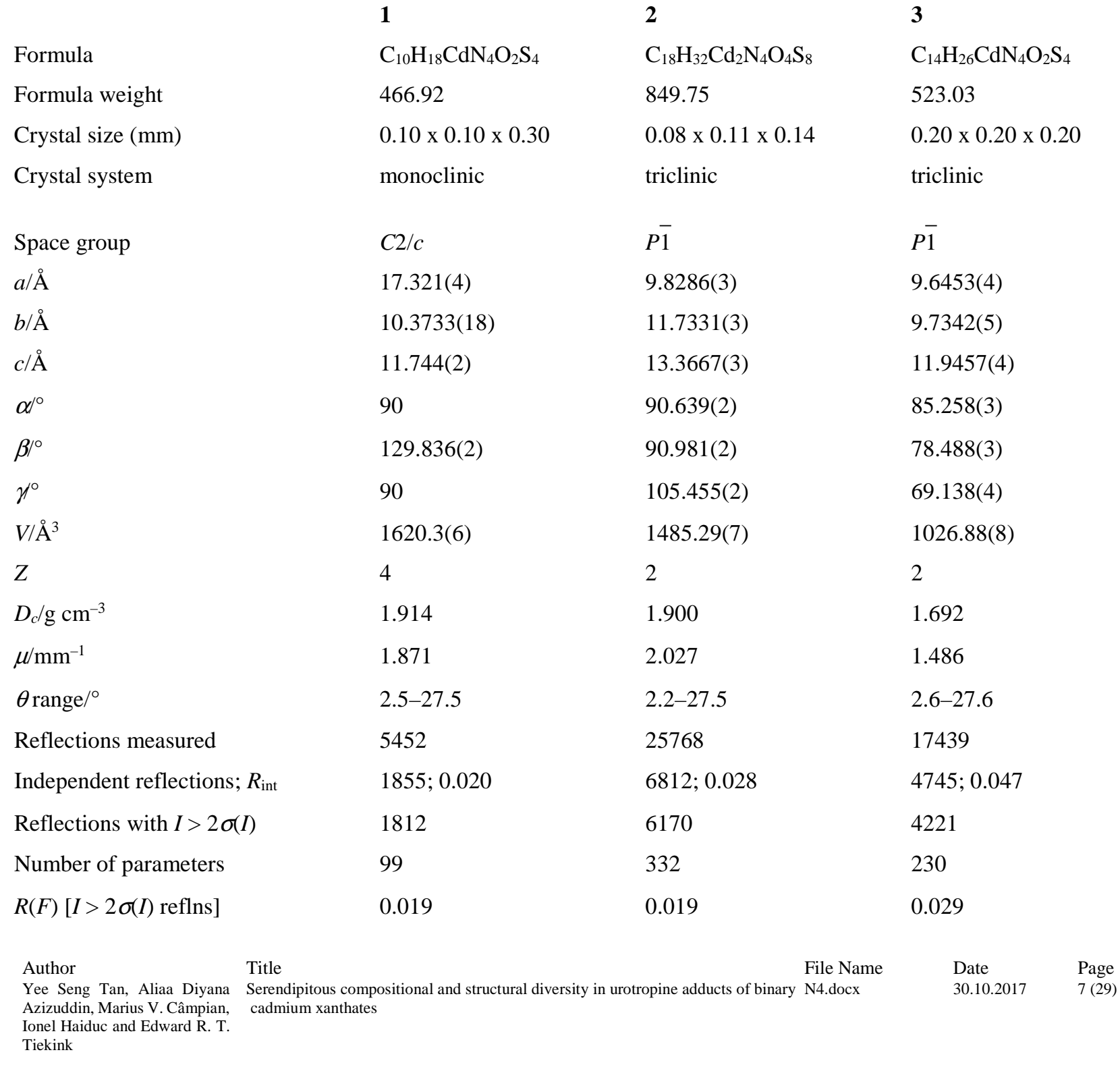




\section{$A ; b$ in wght scheme \\ $w R\left(F^{2}\right)$ (all data)}

GoF $\left(F^{2}\right)$

$0.021 ; 2.409$

0.046

1.07
$0.014 ; 0.599$

0.042

1.04
$0.026 ; 0.251$

0.063

1.04

$\Delta \rho_{\max , \min }\left(\mathrm{e}^{\circ} \AA^{-3}\right) \quad 0.54,-0.62 \quad 0.51,-0.43 \quad 1.20,-1.00^{I}$ Supplementary Material: Crystallographic data (excluding structure factors) for the structures reported in this paper have been deposited with the Cambridge Crystallographic Data Centre as supplementary publications no. CCDC-1409580 to 1409582 . Copies of available material can be obtained free of charge, on application to CCDC, 12 Union Road, Cambridge CB2 1EZ, UK, (fax: +44-(0)1223-336033 or e-mail: deposit@ ccdc.cam.ac.uk). The list of Fo/Fc-data is available from the author up to one year after the publication has appeared.
Author
Title
File Name 


\section{Powder X-ray Diffraction}

Powder X-ray diffraction (PXRD) data were recorded with a PANalytical Empyrean XRD system with $\mathrm{Cu} \mathrm{K} \alpha 1$ radiation $(\lambda=1.54056 \AA)$ in the $2 \theta$ range of 5 to $50^{\circ}$ with a step size of $0.026^{\circ}$. The comparison between experimental and calculated (from CIFs) PXRD patterns was performed with X'Pert HighScore Plus [76].

\section{Results and Discussion}

\section{Syntheses and spectroscopy}

The reactions between $\mathrm{Cd}\left(\mathrm{S}_{2} \mathrm{COR}\right)_{2}, \mathrm{R}=\mathrm{Me}$, Et and iPr, and hmta yielded three new compounds regardless of the ratio between the reagents, i.e. 1:1, 2:1 and 1:2. The structures of $\mathrm{Cd}\left(\mathrm{S}_{2} \mathrm{COMe}\right)_{2}$ (hmta) (1), $\mathrm{Cd}\left(\mathrm{S}_{2} \mathrm{COEt}\right)_{2}(\mathrm{hmta})_{0.5} \quad$ (2) and $\mathrm{Cd}\left(\mathrm{S}_{2} \mathrm{COiPr}\right)_{2}$ (hmta) (3) were established by single crystal $\mathrm{X}$-ray crystallography as discussed below. Powder X-ray patterns (PXRD) were measured on the powdered samples of the crystals isolated from all reactions. These were compared with the simulated patterns calculated based on the single crystal data (using the respective CIF's) obtained for 13 [76]. The agreement between the experimental and calculated patterns for 1-3 indicates the single crystal results are representative of the isolated materials, see Supplementary Material Fig. S1.

The multiplicity and integration observed in the ${ }^{1} \mathrm{H}$ NMR spectra were consistent with the expected formulae. The resonances due to the $\mathrm{CH}_{2}$ protons of hmta were observed as singlets at $\delta 4.60$ (1) and 4.58 (2 and 3 ) compared with $\delta 4.52$ ppm for hmta measured under the same conditions, perhaps indicating a small downfield shift upon coordination. Very small upfield shifts were noted in the ${ }^{13} \mathrm{C}\left\{{ }^{1} \mathrm{H}\right\}$ NMR spectra with $\delta\left(\mathrm{NCH}_{2}\right)$ being $73.4(\mathbf{1})$ and 73.7 (2 and 3) compared with $\delta 73.8 \mathrm{ppm}$ for hmta. By contrast, in terms of the xanthate ligands, the ${ }^{1} \mathrm{H}$ and ${ }^{13} \mathrm{C}\left\{{ }^{1} \mathrm{H}\right\}$ NMR of $\mathbf{1}-\mathbf{3}$ were practically indistinguishable from those recorded for $\mathrm{Cd}\left(\mathrm{S}_{2} \mathrm{COR}\right)_{2}$, $\mathrm{R}=\mathrm{Me}$, Et and iPr. Further discussion relating to the question whether hmta remains coordinated in solution is found below. At least, the appearance of a single resonance for the hmta molecules in the ${ }^{1} \mathrm{H}$ and ${ }^{13} \mathrm{C}\left\{{ }^{1} \mathrm{H}\right\}$ spectra of $\mathbf{1}-\mathbf{3}$ indicates fluxional behaviour. The IR spectra (see Supplementary Material Fig. S2) showed characteristic absorptions, i.e. $v_{\text {as }}(\mathrm{C}-\mathrm{H}), v_{\mathrm{s}}(\mathrm{C}-\mathrm{H})$ and $v(\mathrm{C}-\mathrm{N})$, due to hmta. In the same way, characteristic xanthate absorptions, i.e. $v(\mathrm{C}-\mathrm{O})$ and $v(\mathrm{C}-\mathrm{S})$, were observed, with systematic blue-shifts noted for the latter.

\section{Crystal and molecular structures}

The crystal structures of $\left[\mathrm{Cd}\left(\mathrm{S}_{2} \mathrm{COMe}\right)_{2}(\mathrm{hmta})\right]_{\mathrm{n}} \quad(\mathbf{1})$, $\left[\mathrm{Cd}\left(\mathrm{S}_{2} \mathrm{COEt}\right)_{2}(\mathrm{hmta})_{0.5}\right]_{\mathrm{n}}$ (2) and $\mathrm{Cd}\left(\mathrm{S}_{2} \mathrm{COiPr}\right)_{2}(\mathrm{hmta})$ (3) were established by X-ray crystallography; selected geometric parameters are given in the respective figure captions. The crystallographic asymmetric unit in the crystal structure

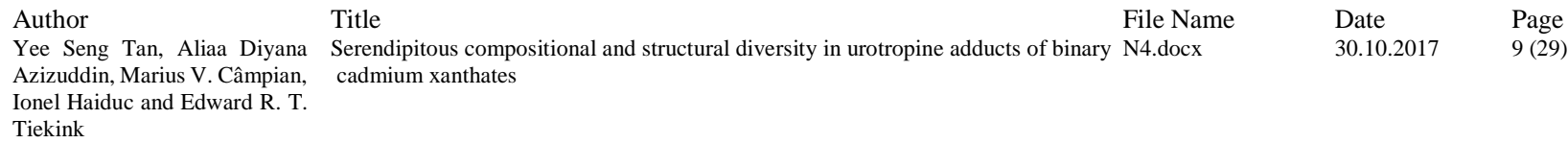


of 1 comprises half of $\mathrm{Cd}\left(\mathrm{S}_{2} \mathrm{COMe}\right)_{2}$, with the $\mathrm{Cd}$ atom located on a crystallographic centre of inversion, and half of a molecule of hmta, as this is located about a 2-fold axis, Fig. $3 \mathrm{a}$, so that there is a $1: 1$ ratio between $\mathrm{Cd}\left(\mathrm{S}_{2} \mathrm{COMe}\right)_{2}$ and hmta. The methylxanthate ligand chelates the cadmium and forms almost symmetric $\mathrm{Cd}-\mathrm{S}$ bond lengths. From symmetry, the cadmium atoms is six-coordinate within a $\mathrm{N}_{2} \mathrm{~S}_{4}$ donor set with the nitrogen atoms being mutually trans. Distortions from the ideal octahedral geometry are related to the acute bite angle of the xanthate ligand, $\mathrm{S} 1-\mathrm{Cd}-\mathrm{S} 2$ is $68.572(13)^{\circ}$. The N4 ligand is $\mu_{2}$-bidentate, spanning two cadmium atoms so that a one-dimensional coordination polymer is formed. This is orientated along the [101] direction and has a zigzag topology, Fig. 3b. In the crystal packing, chains pack with no specific intermolecular interactions between them according to the criteria embodied in PLATON [74]; the unit cell contents for $\mathbf{1}$ are shown in Fig. 3c.

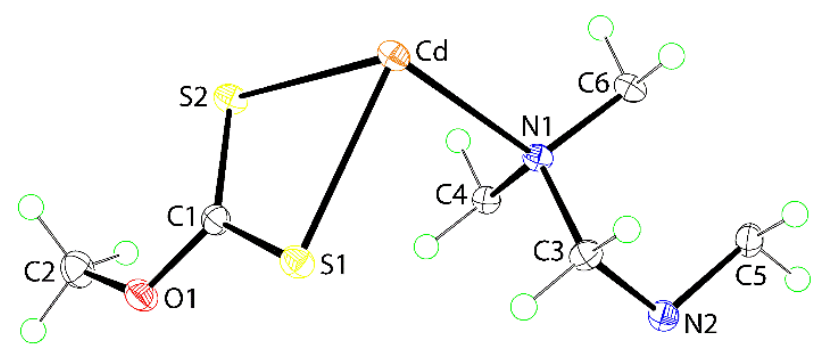

(a)

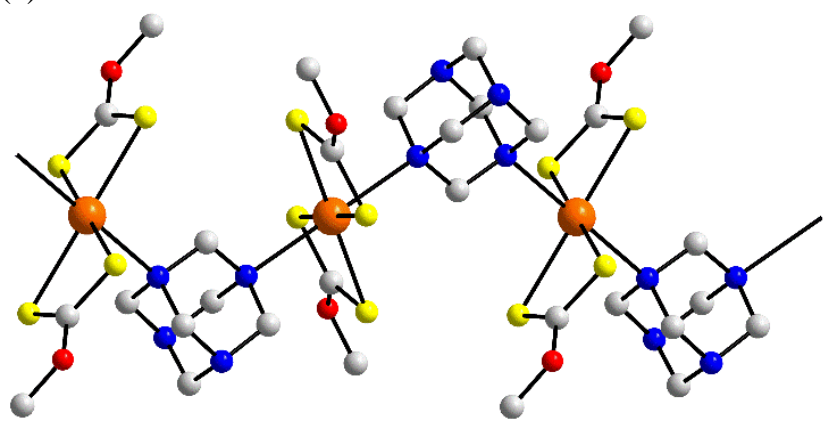

(b)

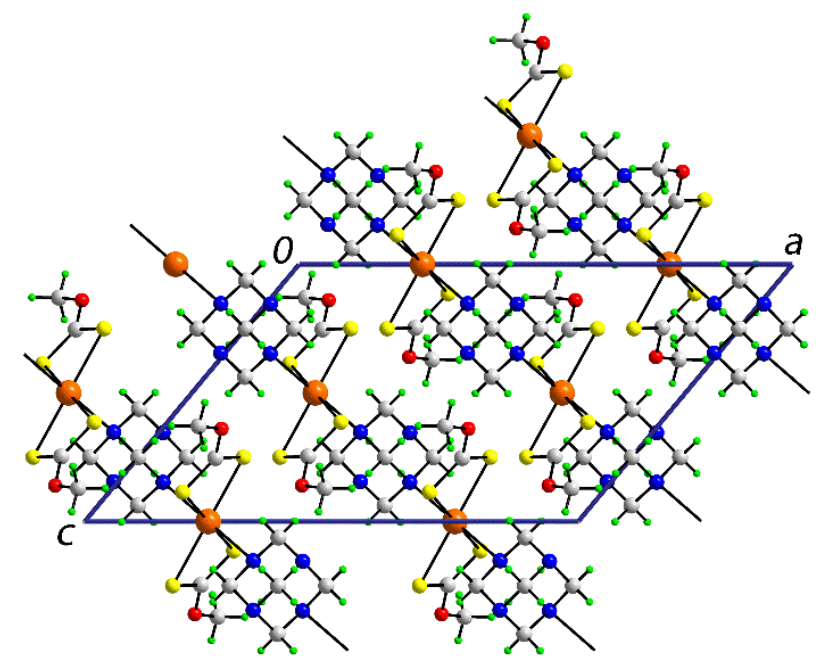

(c)

Fig. 3. (a) The asymmetric unit in the crystal structure of $\mathbf{1}$ showing atom-labelling and displacements ellipsoids at the 
$50 \%$ probability level; the Cd atom is located on a crystallographic centre of inversion and N4 is located about a 2-fold axis. Selected geometric parameters: Cd-S1 2.6435(7), CdS2 2.6844(6) and Cd-N1 2.5476(15) ̊. (b) The one-dimensional coordination polymer with hydrogen atoms removed for reasons of clarity. (c) A view in projection down the baxis of the unit cell contents, showing the supramolecular chains to pack without specific interactions between them.

The asymmetric unit in the crystal structure of $\mathbf{2}$ comprises three distinct cadmium atoms, two of which lie on a centre of inversion with the other in a general position, six distinct ethylxanthate ligands and an entire molecule of hmta, Fig. 4a, so that there is a $2: 1$ ratio between $\mathrm{Cd}\left(\mathrm{S}_{2} \mathrm{COEt}\right)_{2}$ and hmta. Each cadmium atom is chelated by two ethylxanthate ligands with the $\mathrm{Cd}-\mathrm{S}$ bond lengths lying in a relatively narrow range, i.e. $2.6056(5)$ to $2.6683(4) \AA$. The $\mathrm{Cd} 1$ atom is also coordinated by a nitrogen atom from hmta, and from symmetry, each of the $\mathrm{Cd} 2$ and $\mathrm{Cd} 3$ atoms are coordinated by two nitrogen atoms. The $\mathrm{Cd} 1$ atom is penta-coordinated, the $\mathrm{NS}_{4}$ donor set defining a distorted square pyramidal geometry with the value of $\tau=0.12$, cf. $\tau$ $=0.00$ and 1.00 for ideal square pyramidal and trigonal bipyramidal geometries, respectively [77]. Distorted octahedral geometries defined by trans $-\mathrm{N}_{2} \mathrm{~S}_{4}$ donor sets, as for $\mathbf{1}$, are found for the $\mathrm{Cd} 2$ and $\mathrm{Cd} 3$ atoms. The $\mathrm{Cd} 2$ and $\mathrm{Cd} 3$ atoms are bridged by hmta ligands to form a one-dimensional zigzag chain along the $c$-axis, akin to that seen in $\mathbf{1}$. The clear difference in $\mathbf{2}$ arises with the hmta ligand also connected to terminally bound $\mathrm{Cd}\left(\mathrm{S}_{2} \mathrm{COEt}\right)_{2}$ entities, indicating that the hmta ligand is $\mu_{3}$-tridentate, Fig. $4 \mathrm{~b}$. The terminally bound residues are crucial in assembling chains into a supramolecular layer in the $a c$-plane by $\mathrm{C}-\mathrm{H} \cdots \mathrm{S}$ interactions, which each forming two donor and two acceptor $\mathrm{C}-\mathrm{H} \cdots \mathrm{S}$ interactions, see Fig. $4 \mathrm{c}$ and the figure caption for the geometric details characterising the interactions. The layers stack along the $b$-axis, being separated by hydrophobic interactions, see Fig. 4d.

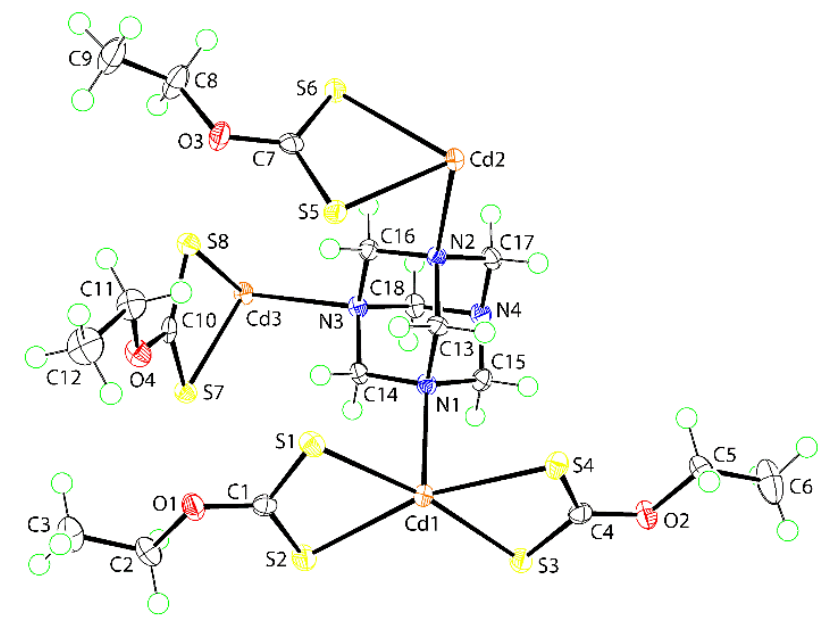

(a) 


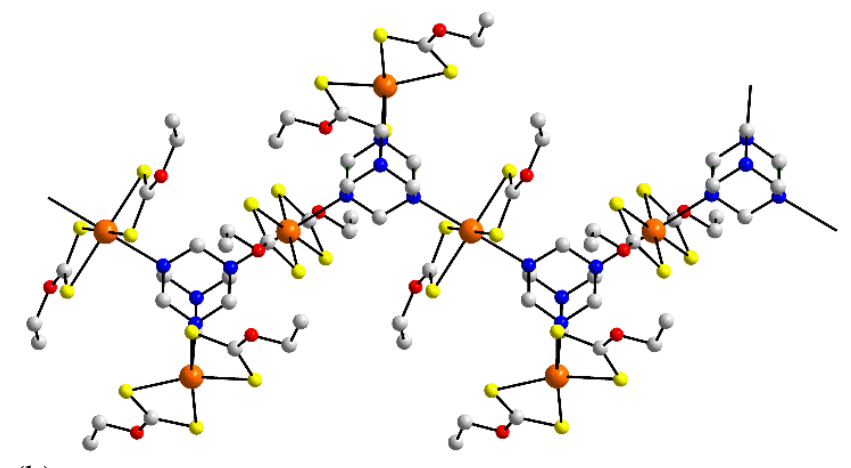

(b)

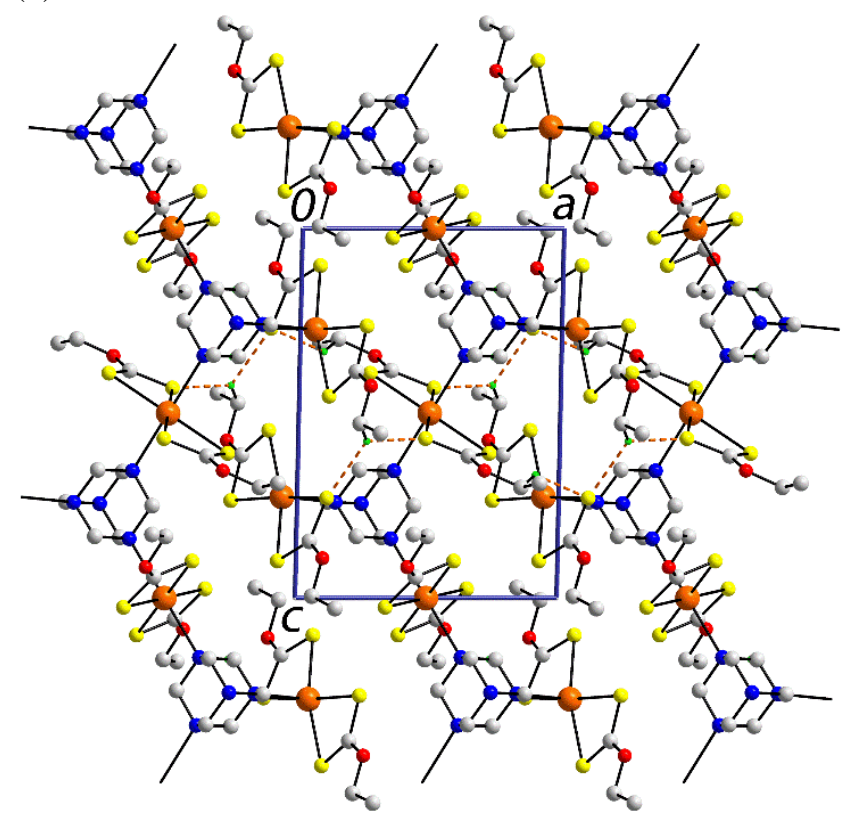

(c)

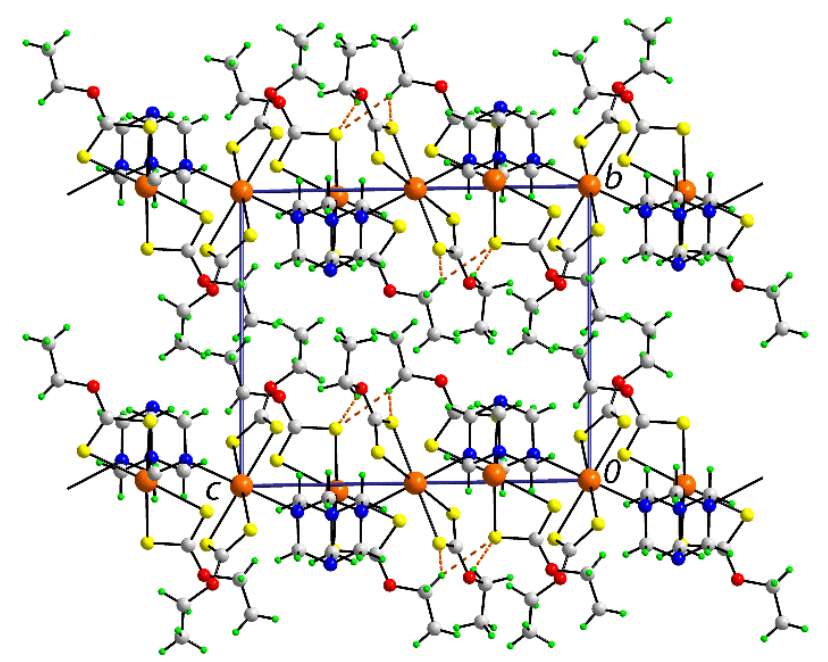

(d)

Fig. 4. (a) The asymmetric unit in the crystal structure of 2 showing atom-labelling and displacements ellipsoids at the $70 \%$ probability level; the $\mathrm{Cd} 2$ and $\mathrm{Cd} 3$ atoms are located on crystallographic centres of inversion. Selected geometric parameters: Cd1-S1 2.6056(5), Cd1-S2 2.6502(5), Cd1-S3 2.6130(5), Cd1-S4 2.6671(5), Cd1-N1 2.4244(15), Cd2-S5 2.6189(5), Cd2-S6 2.6683(4), Cd2-N2 2.5682(14), Cd3-S7 2.6370(4), Cd3-S8 2.6574(4), Cd3-N3 2.5836(14) ̊. (b) The 1-D coordination polymer. (c) The supramolecular layer 
in the $a c$-plane sustained by $\mathrm{C}-\mathrm{H}$...S interactions shown as orange dashed lines. In (b) and (c), the non-interacting hydrogen atoms removed for reasons of clarity. (d) A view in projection down the b-axis of the unit cell contents, showing the supramolecular layers pack along the $c$-axis without specific interactions between them. The geometric parameters for the C-H...S interactions: C5-H5a...S1i = 2.76 $\AA$, C5...S1i $=3.4813(19) \AA$, with angle at $\mathrm{H} 5 \mathrm{a}=130^{\circ}$ for $\mathrm{i}:-\mathrm{x},-\mathrm{y}, 1-\mathrm{z}$; C5-H5a...S5i = $2.83 \AA$, C5...S5i = 3.544(2) $\AA$, with angle at $\mathrm{H} 5 \mathrm{a}=130^{\circ}$; C8-H8b...S1ii $=2.78 \AA$, C8...S1ii = 3.540(2) $\mathrm{A}$, with angle at $\mathrm{H} 8 \mathrm{~b}=134^{\circ}$ for ii: $-1+\mathrm{x}, \mathrm{y}, \mathrm{z}$.

The crystal structure of $\mathbf{3}$ comprises binuclear molecules disposed about a centre of inversion, Fig. 5a. One of the independent isopropylxanthate ligands is chelating, as for $\mathbf{1}$ and 2 , but the other chelates one cadmium atom while simultaneously bridging another in a $\mu_{2} \kappa^{2}$-tridentate mode. The resulting $\mathrm{NS}_{5}$ donor set defines an approximate octahedral geometry with distortions again being traced to the restricted bite angle of the xanthate ligands. In the crystal packing, molecules self-assemble into a supramolecular layer in the $a b$-plane being connected by $\mathrm{C}-\mathrm{H} \cdots \mathrm{N}$ and $\mathrm{C}-\mathrm{H} \cdots \mathrm{S}$ interactions, see Fig. 5b. The layers stack along the $c$-axis, with no specific intermolecular interactions between them, see Fig. $5 c$.

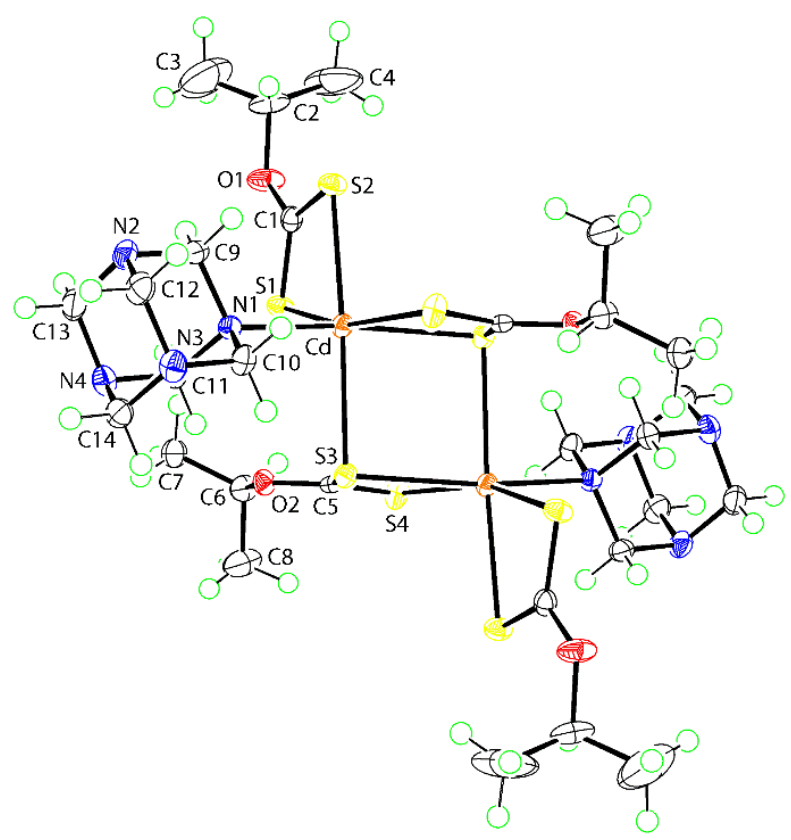

(a) 


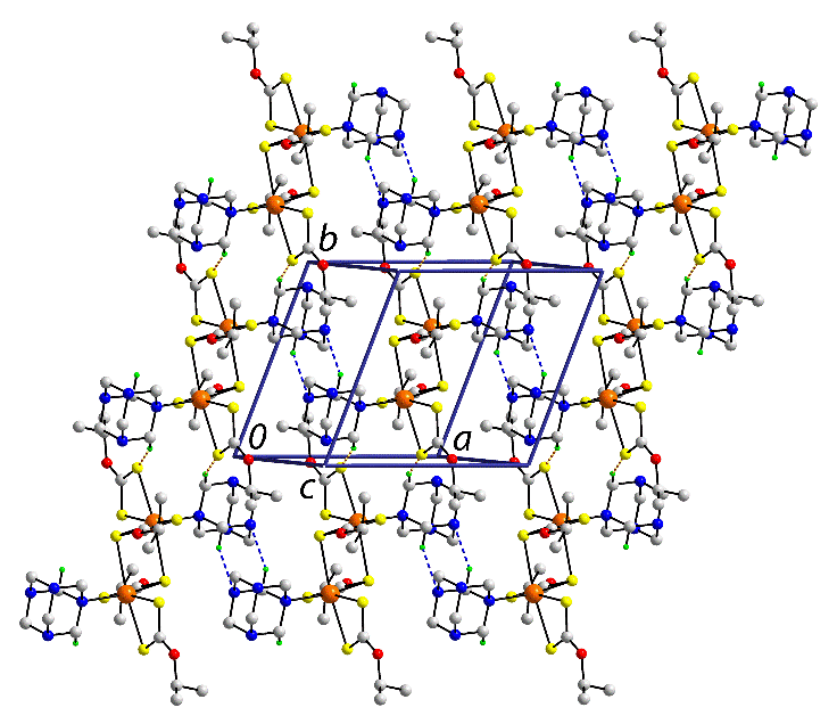

(b)

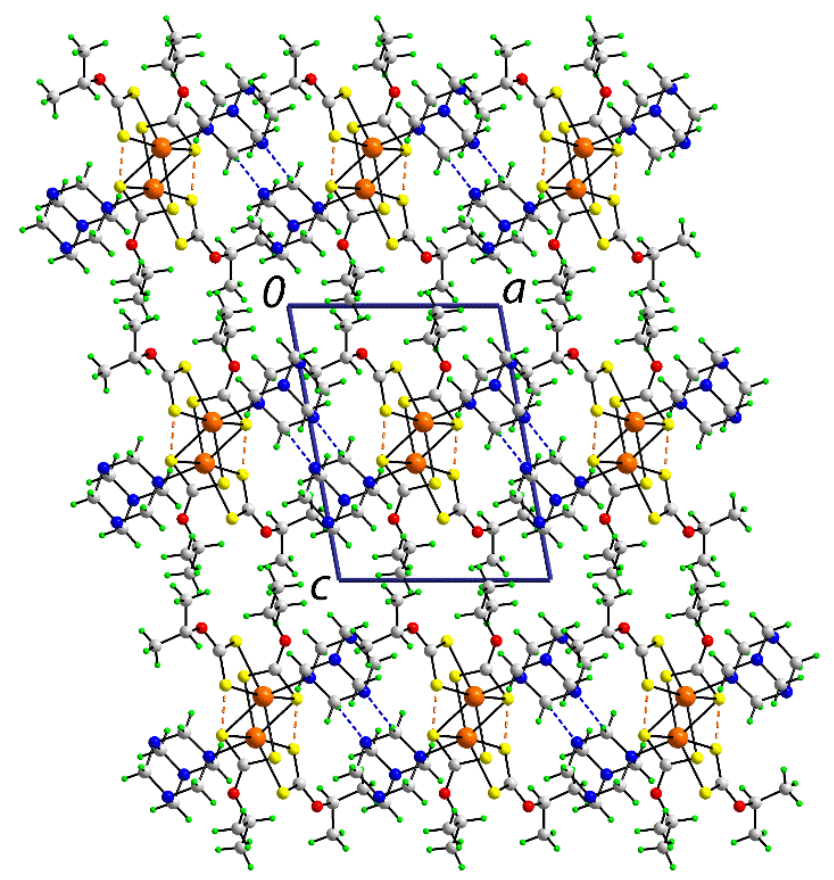

(c)

Fig. 5. (a) The binuclear molecule in the crystal structure of 3 showing atom-labelling and displacements ellipsoids at the $50 \%$ probability level. The molecule is located about a crystallographic centre of inversion; unlabelled atoms are related by the symmetry operation $i$ : $1-x, 1-y, 1-z$. Selected geometric parameters: $\mathrm{Cd}-\mathrm{S} 1$ 2.6348(6), Cd-S2 2.7107(7), Cd-S3 2.7594(6), Cd-S3 ${ }^{\mathrm{i}}$ 2.7101(6), Cd-S4 ${ }^{\mathrm{i}}$ 2.7065(6), Cd-N1 2.395(2) $\AA$. (b) The supramolecular layer in the $a b$-plane sustained by $\mathrm{C}-\mathrm{H} \cdots \mathrm{N}$ and $\mathrm{C}-\mathrm{H} \cdots \mathrm{S}$ interactions shown as blue and orange dashed lines, respectively. Only the hydrogen atoms participating in the intermolecular interactions are shown. (c) A view in projection down the $b$-axis of the unit cell contents, showing the supramolecular layers pack along the $c$-axis without specific interactions between them. Geometric parameters: $\mathrm{C} 10-\mathrm{H} 10 \mathrm{~b} \cdots \mathrm{N} 3^{\mathrm{ii}}=2.57 \AA$, $\mathrm{C} 10 \cdots \mathrm{N} 3^{\mathrm{ii}}=$ $3.440(3) \AA$ with angle at $\mathrm{H} 10 \mathrm{~b}=147^{\circ}$ for $i i: 2-x, 1-y, 1-z$; C9-H9b $\cdots \mathrm{S}^{\mathrm{i}}=2.77 \AA, \mathrm{C} 9 \cdots \mathrm{S} 2^{\mathrm{i}}=3.725(2) \AA$ with angle at $\mathrm{H} 9 \mathrm{~b}=163^{\circ}$ for $i: 1-x, 2-y, 1-z$. 
The structures of one-dimensional, zigzag coordination polymers $\mathbf{1}$ and $\mathbf{2}$ complement the sole previous example of a linear coordination polymer constructed from $\mathrm{Cd}\left(\mathrm{S}_{2} \mathrm{COiPr}\right)_{2}$ and a bridging 4,4'-bipyridine ligand, $\left[\mathrm{Cd}\left(\mathrm{S}_{2} \mathrm{COiPr}\right)_{2}\left(4,4^{\prime} \text {-bipy }\right)\right]_{\mathrm{n}}$ [46]. The zero-dimensional aggregate seen in 3 has only one precedent in the literature, namely in the structure of $\left[\left\{\mathrm{Cd}\left(\mathrm{S}_{2} \mathrm{COEt}\right)_{2}\right\}_{2} \mathrm{~L}_{2}\right]$, where $\mathrm{L}$ is the S-bound thiourea derivative, bis(4-methoxyphenyl)thiourea [78] but resembles the almost universally adopted structural motif adopted by binary cadmium dithiocarbamates [16-34]. As revealed in the previously mentioned review of the inverse coordination propensities of hmta in non-silver containing coordination polymers [67], $\mu_{2^{-}}, \mu_{4^{-}}$and $\mu_{4}$-bridging modes have been observed but terminally bound examples are comparatively rare in this context. In 1,1-dithiolate chemistry, there are no literature precedents of cadmium xanthates or dithiocarbamates with hmta but there are three examples of zero-dimensional aggregates for cadmium dithiophosphates and dithiophosphinates $\left({ }^{-} \mathrm{S}_{2} \mathrm{PR}_{2}\right)$ with hmta. Thus, a mononuclear bis adduct with hmta coordinating in a monodentate fashion was reported in the structure of $\mathrm{Cd}\left[\mathrm{S}_{2} \mathrm{P}(\mathrm{OEt})_{2}\right]_{2}(\mathrm{hmta})_{2}$ [79]. There are two binuclear hemi adducts with hmta, namely $\left\{\mathrm{Cd}\left[\mathrm{S}_{2} \mathrm{P}(\mathrm{O}-\mathrm{sBu})_{2}\right]_{2}\right\}_{2}$ (hmta) [80] and $\left\{\mathrm{Cd}\left[\mathrm{S}_{2} \mathrm{P}(\mathrm{O}-\mathrm{iBu})_{2}\right]_{2}\right\}_{2}$ (hmta) [81], each having hmta in the $\mu_{2}$-bidentate bridging mode.

\section{Rationale for the adoption of different struc- tural motifs in 1-3}

Having discussed the structures of $\mathbf{1}-\mathbf{3}$, the challenge remains to rationalise their formation. First and foremost, DFT calculations show that the electronic profiles of alkylxanthate ligands are independent of $\mathrm{R}$ present in $\mathbf{1}-\mathbf{3}$ [82]. The difference between coordination polymers 1 and $\mathbf{2}$ on the one hand, and that of $\mathbf{3}$ is readily explained in terms of relative size of the iPr substituent. Simply, and consistent with literature precedents [62-66], the bulk of the iPr residue precludes the supramolecular association adopted by the structures with the smaller $\mathrm{R}$ groups. The rationalisation of the different compositions of $\mathbf{1}$ and $\mathbf{2}$ is more subtle. Fig. 6 shows end- and side-on views of the coordination polymers. To a first approximation, the coordination polymers are very similar and the $\mathrm{Cd} . . . \mathrm{Cd}$ separations vindicate this conclusion, being 6.66 and $6.68 \AA$ for $\mathbf{1}$ and $\mathbf{2}$, respectively. To a first approximation, successive $\mathrm{CdS}_{4}$ residues are rotated by approximately $90^{\circ}$ in $\mathbf{1}$ by contrast to approximately $30^{\circ}$ in 2 . The end-on view of 1, Fig. 6a, is instructive in that is reveals a very compact arrangement with the methyl groups shielding the non-coordinating nitrogen atoms of hmta from further interaction. By contrast, a more open arrangement is noted in the end-on view of 2, see Fig. 6c. Presumably, the larger ethyl groups in $\mathbf{2}$ preclude the adoption of the tightknit structure in $\mathbf{1}$. The common feature immediately apparent from the side-on views in Figs $6 b$ and $d$ is the relative orientation of the $-\mathrm{hmta}-\mathrm{Cd}-\mathrm{hmta}-\mathrm{Cd}-$ backbones in both structures. The clear difference relates to the relative orientations of the xanthate ligands. While successive xanthate ligands must be twisted in order to avoid steric clashes between the R substituents, the successive xanthates are not in 
opposite orientations in $\mathbf{2}$ and this opens voids in the polymer to allow the additional coordination of the pendent $\mathrm{Cd}\left(\mathrm{S}_{2} \mathrm{COEt}\right)_{2}$ entities. The crystal packing efficiencies were calculated with PLATON $[17 \mathrm{~g}]$. These are 72.4, 70.9 and $69.2 \%$, respectively, again highlighting the relatively compact structure and efficient packing in $\mathbf{1}$.

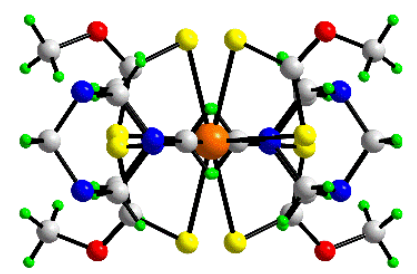

(a)

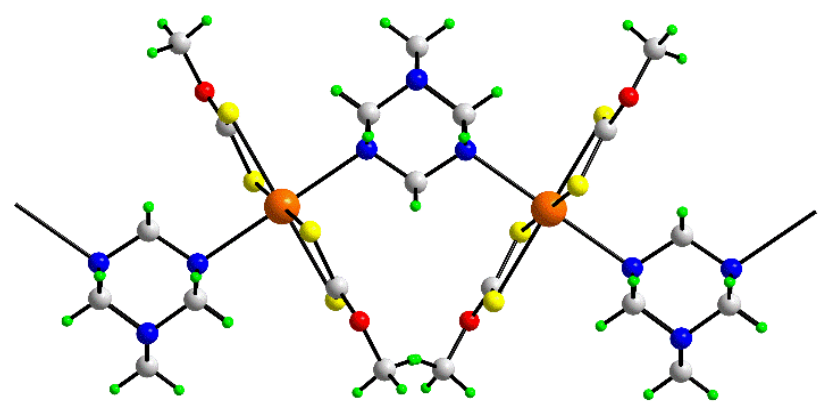

(b)

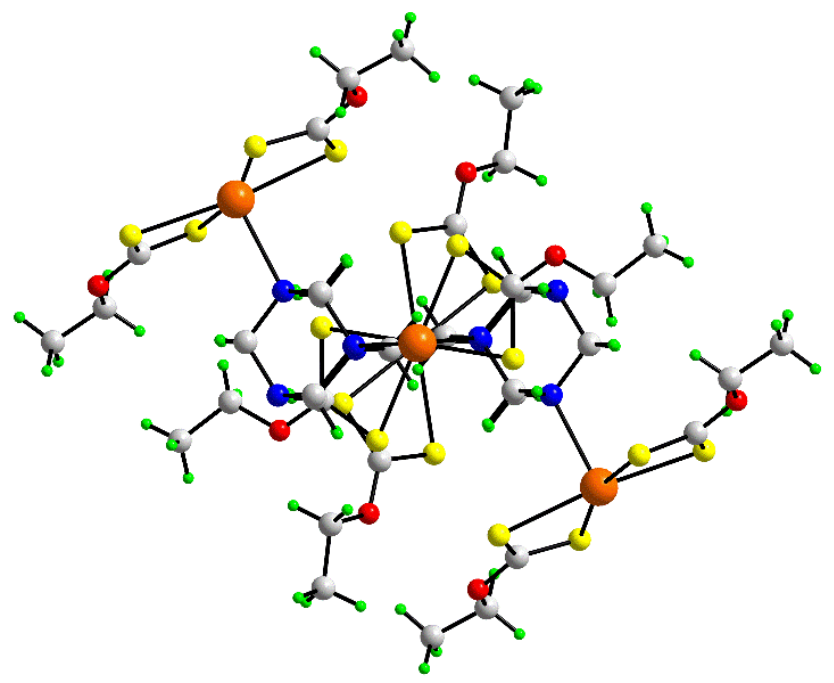

(c)

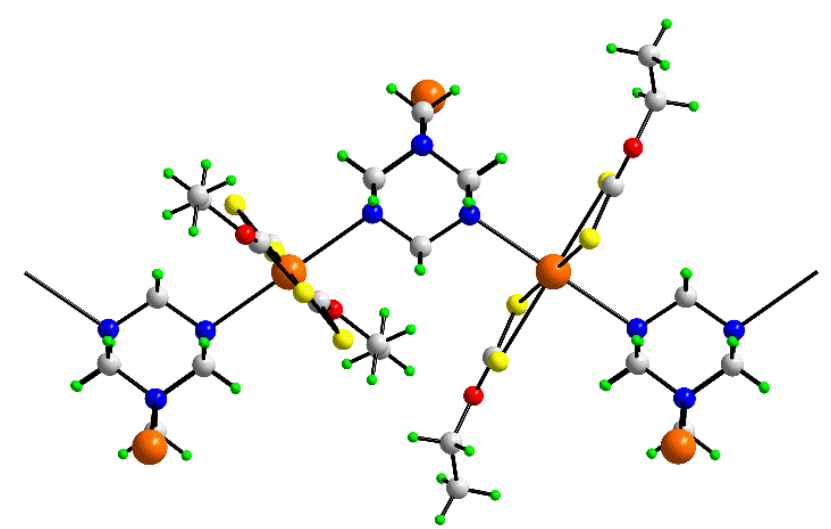

(d) 
Fig. 6. End-on and side-on views of the coordination polymers in (a) and (b) 1, and (c) and (d) 2. In the side-on image for $\mathbf{2}$, only the cadmium atoms of the pendent $\mathrm{Cd}\left(\mathrm{S}_{2} \mathrm{COEt}\right)_{2}$ entities are shown for reasons of clarity.

\section{Thermogravimetric analysis}

Traces for the thermogravimetric analysis for 1-3 are given in Supplementary Material Fig. S3. The decomposition mechanisms of 1-3 were relatively straightforward and led to CdS. Decomposition of $\mathbf{1}$ to CdS was in one step between 109 and $346{ }^{\circ} \mathrm{C}$, with weight loss of $69.7 \%$ cf. calcd. $69.1 \%$. Two discernible steps were noted for 2 . The first step between 120 and $650{ }^{\circ} \mathrm{C}$ correlated with the loss of three xanthate anions and hmta with a weight loss of $57.4 \% \mathrm{cf}$. calcd. $59.3 \%$. The second step between 650 and $866^{\circ} \mathrm{C}$ left a 32.9 $\%$ residue cf. calcd. $34.0 \%$ corresponding to CdS. The decomposition mechanism of $\mathbf{3}$ was basically the same as for $\mathbf{2}$ with three xanthates and two hmta molecules being lost initially between 132 and $421{ }^{\circ} \mathrm{C}$ (weight loss $64.8 \%$ cf. calcd. $65.6 \%$ ). The following step between 421 and $686^{\circ} \mathrm{C}$ left a $28.0 \%$ residue cf. calcd. $27.6 \%$ corresponding to CdS. Cadmium xanthates and their nitrogen adducts are well known to be useful as synthetic precursors for CdS nanoparticles [37, 83-85], and the results herein suggest that hmta adducts are able to produce $\mathrm{CdS}$ relatively cleanly.

\section{UV-visible and photoluminescence studies}

In order to probe further whether N4 remained coordinated in solution, the UV-visible characteristics of 1-3 were compared with those of the parent $\mathrm{Cd}\left(\mathrm{S}_{2} \mathrm{COR}\right)_{2}$ compounds, see Table 2 for data. The spectra were obtained in ethanol:acetonitrile (1:1) solutions, each at concentrations of 10 and 100 $\mu \mathrm{M}$, and were very similar to each other. An intense, highenergy band was observed at $296 \mathrm{~nm}$ for each of 1-3. This transition is assigned as an intra-ligand $\pi \rightarrow \pi^{*}$ charge transfer [89] Low intensity bands were observed around $360 \mathrm{~nm}$ which are assigned to ligand metal charge transfer (LMCT) bands[89]. The similarity of the spectra is consistent with lack of significant influence of the alkyl group on electronic transitions $[82,89,90]$. The spectra of the $\mathrm{Cd}\left(\mathrm{S}_{2} \mathrm{COR}\right)_{2} \mathrm{com}-$ pounds exhibit very similar absorptions but with distinctive values of $\varepsilon$ in the case of the $\mathrm{R}=\mathrm{Me}$ and Et compounds but, with near equivalence when $\mathrm{R}=\mathrm{iPr}$. More distinctive responses were evidenced from a photoluminescence study.

Photoluminescence measurements were carried out at room temperature on $1 \mathrm{mM}$ solutions in acetonitrile:ethanol (1:1) with excitation wavelengths of 295 and $360 \mathrm{~nm}$, Table 2. With $\lambda_{\text {ex }}=295 \mathrm{~nm}$, only the $\mathrm{R}=$ Me compounds showed emissions at around $710 \mathrm{~nm}$. With $\lambda_{\mathrm{ex}}=360 \mathrm{~nm}, \mathbf{1}$ and 2 showed strong emissions at $554 \mathrm{~nm} ; 3$ was non-emissive. By contrast, the $\mathrm{Cd}\left(\mathrm{S}_{2} \mathrm{COR}\right)_{2}$ compounds showed emissions at wavelengths greater than $610 \mathrm{~nm}$. This distinctive behaviour suggests that the N4 ligands remain coordinated in $\mathbf{1 - 3}$, at least in acetonitrile:ethanol $(1: 1)$ solutions.

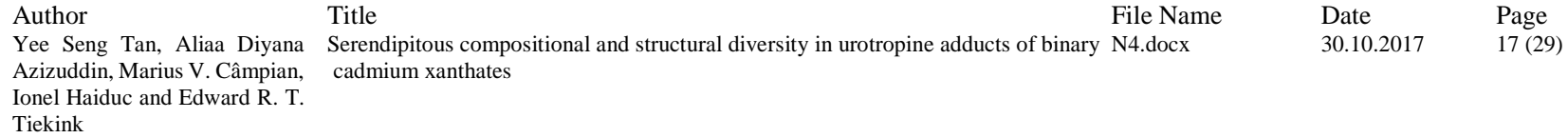


Table 2. UV-visible $\left(\lambda_{\max }, \mathrm{nm} ; \varepsilon, \mathrm{Lcm}^{-1} \mathrm{~mol}^{-1}\right)$ and photoluminescence data $\left(\lambda, \mathrm{nm} ; \lambda_{\mathrm{ex}}=295\right.$ and $\left.360 \mathrm{~nm}\right)$ for $\mathrm{Cd}\left(\mathrm{S}_{2} \mathrm{COR}\right)_{2}, \mathrm{R}=\mathrm{Me}, \mathrm{Et}$ and iPr, and $\mathbf{1}-\mathbf{3}$.

\begin{tabular}{|c|c|c|c|c|c|}
\hline \multirow{3}{*}{ Compd } & \multicolumn{3}{|c|}{ solution } & \multicolumn{2}{|c|}{ solid-state $(77 \mathrm{~K})$} \\
\hline & \multicolumn{2}{|l|}{ UV-vis } & \multicolumn{3}{|c|}{ photoluminescence } \\
\hline & $\lambda_{\max }$ & $\lambda_{\mathrm{em}}(295)$ & $\lambda_{\text {em }}(360)$ & $\lambda_{\mathrm{em}}(295)$ & $\lambda_{\text {em }}(360)$ \\
\hline \multirow[t]{2}{*}{$\mathrm{Cd}\left(\mathrm{S}_{2} \mathrm{COMe}\right)_{2}$} & $296(11,594)$ & 707 & 612 & 589 & 598 \\
\hline & $358(254)$ & & & 693 & 694 \\
\hline \multirow[t]{3}{*}{$\mathrm{Cd}\left(\mathrm{S}_{2} \mathrm{COEt}\right)_{2}$} & $298(18,295)$ & - & 642 & 703 & 490 \\
\hline & 362 (137) & & & & 650 \\
\hline & & & & & 698 \\
\hline \multirow[t]{3}{*}{$\mathrm{Cd}\left(\mathrm{S}_{2} \mathrm{COiPr}\right)_{2}$} & $299(20,471)$ & - & 612 & 493 & 614 \\
\hline & $362(145)$ & & & 605 & \\
\hline & & & & 697 & \\
\hline \multirow[t]{2}{*}{1} & $296(20,270)$ & - & 554 & 609 & 586 \\
\hline & $362(155)$ & & & 701 & \\
\hline \multirow[t]{2}{*}{2} & $296(35,150)$ & 710 & 554 & 489 & 542 \\
\hline & $360(386)$ & & & 709 & \\
\hline \multirow[t]{2}{*}{3} & $296(21,680)$ & - & - & 661 & 602 \\
\hline & $363(146)$ & & & 693 & \\
\hline
\end{tabular}


Photoluminescence measurements were also carried out in the solid-state at the same excitation wavelengths, Table 2. Consistent with expectation, blue-shifts and increasing intensities of the bands were observed as the temperatures at which the experiments were measured were decreased. Representative spectra recorded at $77 \mathrm{~K}$ for $\mathbf{1 - 3}$ are given in Supplementary Material Fig. S4 and show that while distinctive bands for 2 and, especially, zero-dimensional 3 were observed, those for 1 were poorly resolved. With $\lambda_{\mathrm{ex}}=295 \mathrm{~nm}$, two bands were observed for each of 1-3 with the high-energy band varying from a low 489 for 2 to a high 661 for 3 . A low-energy band, which was significantly more intense in $\mathbf{2}$ but had comparable intensities for $\mathbf{1}$ and $\mathbf{3}$, appeared around $700 \mathrm{~nm}$. A single emission appeared when $\lambda_{\text {ex }}$ was $360 \mathrm{~nm}$. The solid-state spectra for 1-3 are quite distinct from those observed for $\mathrm{Cd}\left(\mathrm{S}_{2} \mathrm{COR}\right)_{2}$ indicating that the presence of the hmta ligand influences the electronic transitions involving the xanthate chromophores.

\section{Conclusions}

Three new compounds have been isolated from 1:1, 1:2 and 2:1 solutions containing $\mathrm{Cd}\left(\mathrm{S}_{2} \mathrm{COR}\right)_{2}, \mathrm{R}=\mathrm{Me}, \mathrm{Et}$ and $\mathrm{iPr}$, and hmta. Compound $\mathbf{1}$ is a coordination polymer with a zigzag topology. The basic structure of $\mathbf{2}$ is as for $\mathbf{1}$ but with pendant $\mathrm{Cd}\left(\mathrm{S}_{2} \mathrm{COEt}\right)_{2}$ entities, indicating the hmta ligand is $\mu_{3}$-tridentate. A binuclear molecule is observed in $\mathbf{3}$ with terminally bound hmta ligands. The zero-dimensional aggregate in $\mathbf{3}$ is correlated with the steric bulk of the iPr groups. The compact arrangement in $\mathbf{1}$ cannot accommodate the larger ethyl groups in $\mathbf{2}$ which enables additional coordination of $\mathrm{Cd}\left(\mathrm{S}_{2} \mathrm{COEt}\right)_{2}$ entities. This study expands the range of cadmium xanthates with potentially bridging ligands and reveals unexpected and interesting structural diversity suggesting further investigations are well warranted.

\section{Acknowledgments}

This research was supported by the High Impact Research MoE Grant UM.C/625/1/HIR/MoE/SC/03 from the Ministry of Higher Education, Malaysia. 


\section{References}

[1] E. R. T. Tiekink, I. Haiduc, Prog. Inorg. Chem. 2005, 54, 127 .

[2] P. J. Heard, Prog. Inorg. Chem. 2005, 53, 1.

[3] G. Hogarth, Prog. Inorg. Chem. 2005, 53, 71.

[4] J. Cookson, P. D. Beer, Dalton Trans. 2007, 1459.

[5] I. Haiduc, D. B. Sowerby, Polyhedron 1996, 15, 2469.

[6] I. Haiduc, 1,1-Dithiolato Ligands, in vol. Comprehensive Coordination Chemistry II. From Biology to Nanotechnology, J. A. McCleverty, T. J. Meyer, Editors-in-Chief, Volume 1, Fundamentals, Edited by A. B. P. Lever, Elsevier, 2003, Chapter $1.15,349$.

[7] I. Haiduc, 1,1-Dithiolato ligands and related selenium and tellurium compounds, in vol. Handbook of Chalcogen Chemistry. New Perspectives in sulfur, selenium and tellurium, Edited by F. Devillanova, RSC Publishing, The Royal Society of Chemistry, London, 2007, 593.

[8] B. F. Abrahams, B. F. Hoskins, E. R. T. Tiekink, G. Winter, Aust. J. Chem. 1988, 41, 1117.

[9] V. G. Young Jr., E. R. T. Tiekink, Acta Crystallogr. Sect. E: Struct. Rep. Online 2002, 58, m537.

[10] H. M. Rietveld, E. N. Maslen, Acta Crystallogr. 1965, 18, 429.

[11] X.-H. Jiang, W.-G. Zhang, Y. Zhong, F.-X. Wei, S.-L. Wang, Chin. J. Inorg. Chem. 2002, 18, 615.

[12] Y. Iimura, T. Ito, H. Hagihara, Acta Crystallogr. Sect. B: Struct. Crystallogr. Cryst. Chem. 1972, 28, 2271.

[13] Y. Iimura, Sci. Pap. Inst. P. C. R. (Jpn.) 1973, 67, 43.

[14] D. W. Tomlin, T. M. Cooper, D. E. Zelmon, Z. Gebeyehu, J. M. Hughes, Acta Crystallogr. Sect. C: Cryst. Struct. Commun. 1999, 55, 717.

[15] E. R. T. Tiekink, Acta Crystallogr. Sect. C: Cryst. Struct. Commun. 2000, 56, 1176.

[16] A. Domenicano, L. Torelli, A. Vaciago, L. Zambonelli, J. Chem. Soc. A. 1968, 1351.

[17] E. A. Shugam, V. M. Agre, Kristallografiya 1968, 13, 253.

[18] C. M. Dee, E. R. T. Tiekink, Z. Kristallogr.-New Cryst. Struct. 2002, 217, 85.

[19] A. V. Ivanov, O. V. Loseva, A. V. Gerasimenko, Koord. Khim. 2008, 34, 413.

[20] D. V. Konarev, A. Yu. Kovalevsky, S. S. Khasanov, G. Saito, D. V. Lopatin, A. V. Umrikhin, A. Otsuka, R. N. Lyubovskaya, Eur. J. Inorg. Chem. 2006, 1881.

[21] E. Jian, Z. Wang, Z. Bai, X. You, H. K. Fun, H. K, K. Chinnakali, J. Chem. Cryst. 1999, 29, 227. 
[22] A. V. Ivanov, A. A. Konzelko, A. V. Gerasimenko, M. A. Ivanov, O. N. Antsutkin, W. Forsling, Russ. J. Inorg. Chem. 2005, 50, 1827.

[23] F.-F. Jian, Z.-X. Wang, H. K. Fun, Z.-P. Bai, X.Z. You, Acta Crystallogr. Sect. C: Cryst. Struct. Commun. 1999, 55, 174.

[24] M. J. Cox, E. R. T. Tiekink, Z. Kristallogr. 1999, 214,670 .

[25] J. S. Casas, A. Sanchez, J. Bravo, S. Garcia-Fontan, E. E. Castellano, M. M. Jones, Inorg. Chim. Acta 1989, 158, 119.

[26] L. A. Glinskaya, S. M. Zemskova, R. F. Klevtsova, Zh. Strukt. Khim. 1999, 40, 979.

[27] M. Saravanan, K. Ramalingam, G. Bocelli, R. Olla, Appl. Organomet. Chem. 2004, 18, 103.

[28] X. Yin, W.-G. Zhang, Q.-J. Zhang, J. Fan, C. S. Lai, E. R. T. Tiekink, Appl. Organomet. Chem. 2004, 18, 139.

[29] Y. Zhong, W. Zhang, J. Fan, M. Tan, C. S. Lai, E. R. T. Tiekink, Acta Crystallogr. Sect. E: Struct. Rep. Online 2004, 60, m1633.

[30] A. V. Ivanov, A. V. Gerasimenko, A. A. Konzelko, M. A. Ivanov, O. N. Antzutkin, W. Forsling, Inorg. Chim. Acta 2006, 359, 3855.

[31] A. Manohar, K. Ramalingam, G. Bocelli, A. Cantoni, Pol. J. Chem. 2005, 79, 671.

[32] V. M. Agre, E. A. Shugam, Kristallografiya 1972, 17, 303.

[33] S. Thirumaran, N. Srinivasan, V. Sharma, V. K. Gupta, Rajnikant, X-ray. Str. Anal. Online 2012, 28, 21.

[34] R. Kant, V. K. Gupta, K. Kapoor, P. Valarmathi, S. Thirumaran, Acta Crystallogr. Sect. E: Struct. Rep. Online 2012, 68, m12.

[35] B. Moulton, M. J. Zaworotko, Chem. Rev. 2001, $101,1629$.

[36] J.-P. Zhang, X.-C. Huang, X.-M., Chen, Chem. Soc. Rev. 2009, 38, 2385.

[37] Y. S. Tan, A. L. Sudlow, K. C. Molloy, Y. Morishima, K. Fujisawa, W. J. Jackson, W. Henderson, S. N. Bt. A. Halim, S. W. Ng, E. R. T. Tiekink, Cryst. Growth Des. 2013, 13, 3046.

[38] Y. S. Tan, S. N. A. Halim, E. R. T. Tiekink, Z. Kristallogr. 2015, submitted.

[39] V. Kumar, V. Singh, A. N. Gupta, K. K. Manar, M. G. B. Drew, N. Singh, CrystEngComm 2014, 16, 6765 .

[40] S. L. Lawton, G. T. Kokotailo, Inorg. Chem. 1969, 8, 2410.

[41] J. S. Casas, A. Castiñeiras, M. S. GarciaTasende, A. Sánchez, J. Sordo, E. M. VázquezLópez, Polyhedron 1995, 14, 2055.

[42] A. V. Ivanov, O. V. Loseva, M. A. Ivanov, V. A. Konfederatov, A. V. Gerasimenko, O. N. Antsutkin, W. Forsling, Russ. J. Inorg. Chem. 2007, 52, 1595.

[43] T. Ito, M. Otake, Acta Crystallogr. Sect. C: Cryst. Struct. Commun. 1996, 52, 3024. 
[44] Y.-G. Yin, W. Forsling, D. Bostrom, O. Antzutkin, M. Lindberg, A. Ivanov, Chin. J. Chem. 2003, 21, 291.

[45] A. V. Ivanov, A. V. Gerasimenko, O. Antzutkin, W. Forsling, Inorg. Chim. Acta 2005, 358, 2585.

[46] B. F. Abrahams, B. F. Hoskins, G. Winter, Aust. J. Chem. 1990, 43, 1759.

[47] S. V. Larionov, L. A. Glinskaya, T. G. Leonova, R. F. Klevstsova, J. Struct. Chem. 2005, 46, 1023.

[48] D. Chen, C. S. Lai, E. R. T. Tiekink, Z. Kristallogr. 2002, 217, 747.

[49] M. V. Câmpian, I. Haiduc, E. R. T. Tiekink, Z. Kristallogr. 2013, 228, 187.

[50] J. Fan, F.-X. Wei, W.-G. Zhang, X. Yin, C. S. Lai, E. R. T. Tiekink, Hиахие Xuebao 2007, 65, 2014.

[51] V. Avila, R. E. Benson, G. A. Broker, L. M. Daniels, E. R. T. Tiekink, Acta Crystallogr., Sect. E: Struct. Rep. Online 2006, 62, m1425.

[52] J. Chai, C. S. Lai, J. Yan, E. R. T. Tiekink, Appl. Organomet. Chem. 2003, 17, 249.

[53] C. S. Lai, E. R. T. Tiekink, CrystEngComm 2004, 6, 593.

[54] C. S. Lai, E. R. T. Tiekink, Z. Kristallogr. 2006, 221, 288.

[55] C. S. Lai, E. R. T. Tiekink, J. Mol. Struct. 2006, 796, 114

[56] T. Li, Z.-H. Li, S.-W. Du, Acta Crystallogr., Sect. E: Struct. Rep. Online 2005, 61, m95.

[57] T. Li, Z.-H. Li, S.-M. Hu, S.-Wu Du, J. Coord. Chem. 2006, 59, 945.

[58] T. Li, Z.-H. Li and S.-W. Du, Acta Crystallogr., Sect. E: Struct. Rep. Online 2004, 60, m1912.

[59] C. R. Groom, F. H. Allen, Angew. Chem. Int. Ed. 2014, 53, 662.

[60] N. W. Alcock, Adv. Inorg. Chem. Radiochem., 1972, 15, 1 .

[61] I. Haiduc, Secondary Bonding in J. L. Atwood and J. Steed (Eds), Encyclopedia of Supramolecular Chemistry, Marcel Dekker Inc., New York, 2004, 1215.

[62] C. S. Lai, Y. X. Lim, T. C. Yap, E. R. T. Tiekink, CrystEngComm 2002, 4, 596.

[63] E. R. T. Tiekink, CrystEng Comm 2003, 5, 101.

[64] C. S. Lai, Tiekink, CrystEngComm 2003, 5, 253.

[65] C. S. Lai, Tiekink, CrystEngComm 2004, 6, 221.

[66] E. R. T. Tiekink, CrystEngComm 2006, 8, 104.

[67] A. M. Kirillov, Coord. Chem. Rev. 2011, 255, 1603.

[68] CrystalClear. User Manual. Rigaku/MSC Inc., Rigaku Corporation, The Woodlands, TX, 2005.

[69] T. Higashi, ABSCOR. Rigaku Corporation, Tokyo, Japan, 1995.

[70] Agilent Technologies, CrysAlisPro. Santa Clara, CA, USA. 2014.

[71] G. M. Sheldrick, Acta Crystallogr., Sect. A, Foundat. Crystallogr. 2008, 64, 112.

[72] G. M. Sheldrick, Acta Crystallogr., Sect. C, Cryst. Struct Commun. 2015, 71, 3. 
[73] L. J. Farrugia, J. Appl. Crystallogr. 2012, 45, 849.

[74] A. L. Spek, Acta Crystallogr. Sect. D, Biol. Crystallogr. 2009, 65, 148.

[75] DIAMOND, Visual Crystal Structure Information System, Version 3.1, CRYSTAL IMPACT, Postfach 1251, D-53002 Bonn, Germany, 2006.

[76] X'Pert HighScore Plus. PANalytical B.V. Almelo, The Netherlands, 2009.

[77] A. W. Addison, T. N. Rao, J. Reedijk, J. van Rijn, G. C. Verschoor, J. Chem. Soc. Dalton Trans. 1984, 1349.

[78] Z.-F. Sun, C.-Y. Duan, X.-Z. You, Acta Crystallogr., Sect. C, Cryst. Struct Commun. 1994, 50, 1012.

[79] M. Shimoi, A. Ouchi, M. Aikawa, S. Satoa, Y. Saito, Bull. Chem. Soc. Jpn. 1982, 55, 2089.

[80] L. Bolundut, I. Haiduc, M. F. Mahon, K. C. Molloy, Rev. Chim. (Bucharest Rom.) 2008, 59, 1194.

[81] T. E. Kokina, R. F. Klevtsova, L. A. Glinskaya, S. V. Larionov, Russ. J. Inorg. Chem. 2010, 55, 56.

[82] M. A. Buntine, M. J. Cox, Y. X. Lim, T. C. Yap, E. R. T. Tiekink, Z. Kristallogr. 2003, 218, 56.

[83] D. Barreca, A. Gasparotto, C. Maragno, R. Seraglia, E. Tondello, A. Venzo, V. Krishnan, H. Bertagnolli, Appl. Organomet. Chem. 2005, 19, 59.

[84] D. C. Onwudiwe, T. P. A. Krüger, C. A. Strydom, Mater. Lett. 2014, 116, 154.

[85] A. S. R. Chesman, N. W. Duffy, A. Martucci, L. D. Tozi, T. B. Singha, J. J. Jasieniak, J. Mater. Chem. C 2014, 2, 3247.

[86] D. Barreca, A. Gasparotto, C. Maragno, R. Seraglia, E. Tondello, A. Venzo, V. Krishnan, H. Bertagnolli, Appl. Organomet. Chem. 2005, 19, 59.

[87] D. C. Onwudiwe, T. P. A. Krüger, C. A. Strydom, Mater. Lett. 2014, 116, 154.

[88] A. S. R. Chesman, N. W. Duffy, A. Martucci, L. D. Tozi, T. B. Singha, J. J. Jasieniak, J. Mater. Chem. C 2014, 2, 3247.

[89] J.-G. Kang, J.-S. Shin, D.-H. Cho, Y.-K. Jeong, C. Park, S. F. Soh, C. S. Lai, E. R. T. Tiekink, Cryst. Growth Des. 2010, 10, 1247.

[90] J. M. Bevilacqua, R. Eisenberg, Inorg. Chem. 1994, 33, 2913. 


\section{Serendipitous compositional and structural diversity in urotropine}

\section{adducts of binary cadmium xanthates}

Yee Seng Tan, ${ }^{\mathrm{I}}$ Aliaa Diyana Azizuddin, ${ }^{\mathrm{I}}$ Marius V. Câmpian, ${ }^{\mathrm{II}}$ Ionel Haiducc ${ }^{\mathrm{II}}$ and Edward R. T. Tiekink*I,III

I University of Malaya, Department of Chemistry, 50603 Kuala Lumpur, Malaysia

II Babes-Bolyai University, Department of Chemistry, RO-400028, Cluj-Napoca, Romania

III Sunway University, Centre for Chemical Crystallography, Faculty of Science and Technology, 47500 Bandar Sunway, Selangor Darul Ehsan, Malaysia

****** SUPPLEMENTARY MATERIAL *****

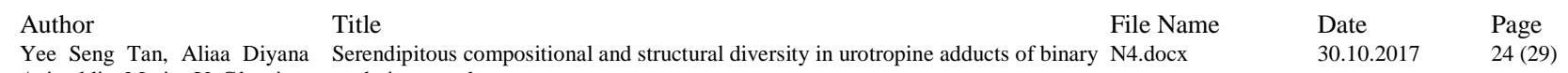


Figure S1. Experimental (red trace) and simulated based on the single crystal structure (blue trace) PXRD patterns for (a) 1, (b) $\mathbf{2}$ and (c) 3. These show that the single crystal data reported herein for each of 1-3 match the structure of the bulk material in each case.

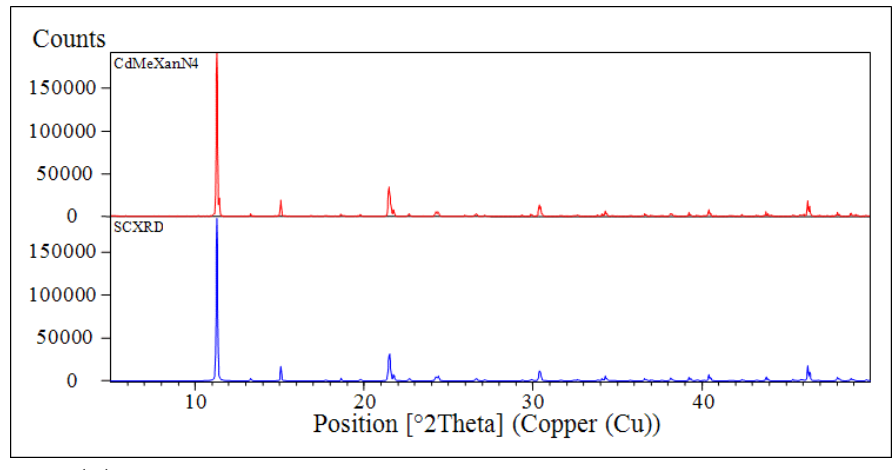

(a)

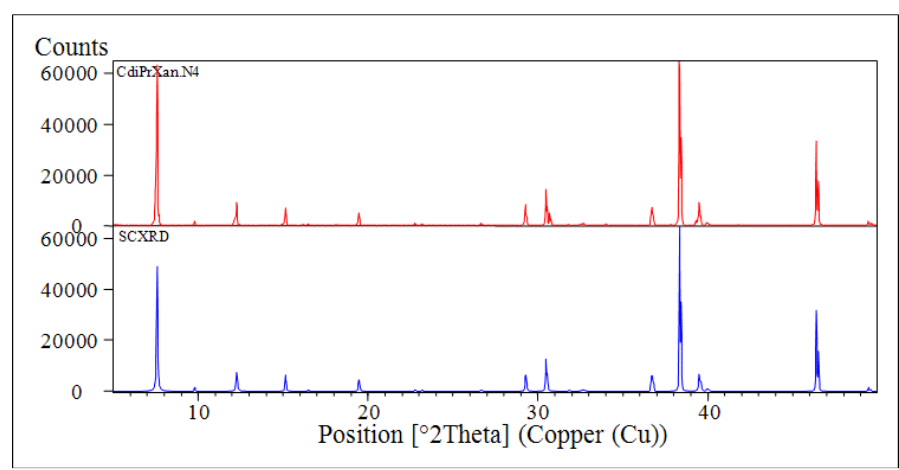

(c)

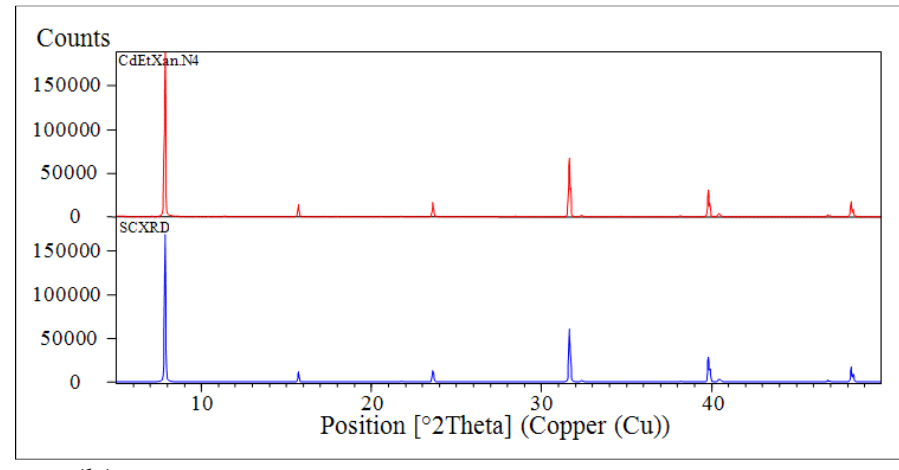

(b) 
Figure S2. IR data for (a) $\mathrm{Cd}\left(\mathrm{S}_{2} \mathrm{COMe}\right)_{2}$ (left-hand image) and $\mathbf{1}$ (right-hand image), (b) $\mathrm{Cd}\left(\mathrm{S}_{2} \mathrm{COEt}\right)_{2}$ and $\mathbf{2}$, and (c) $\mathrm{Cd}\left(\mathrm{S}_{2} \mathrm{COiPr}\right)_{2}$ and 3.

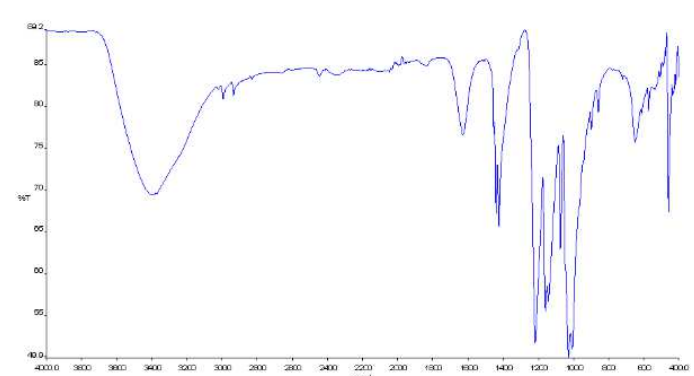

(a)

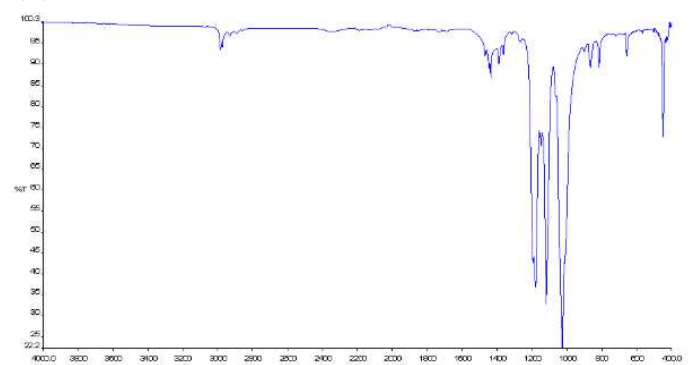

(b)

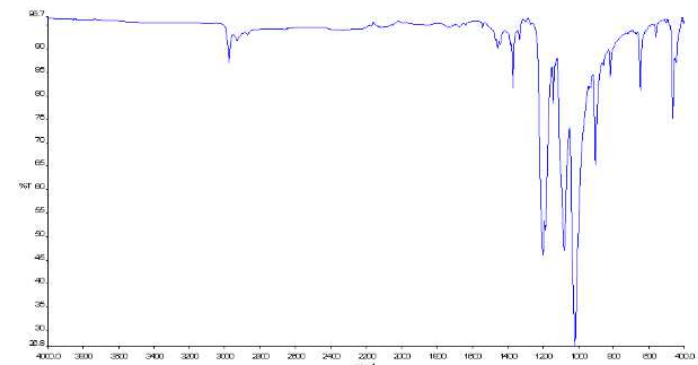

(c)
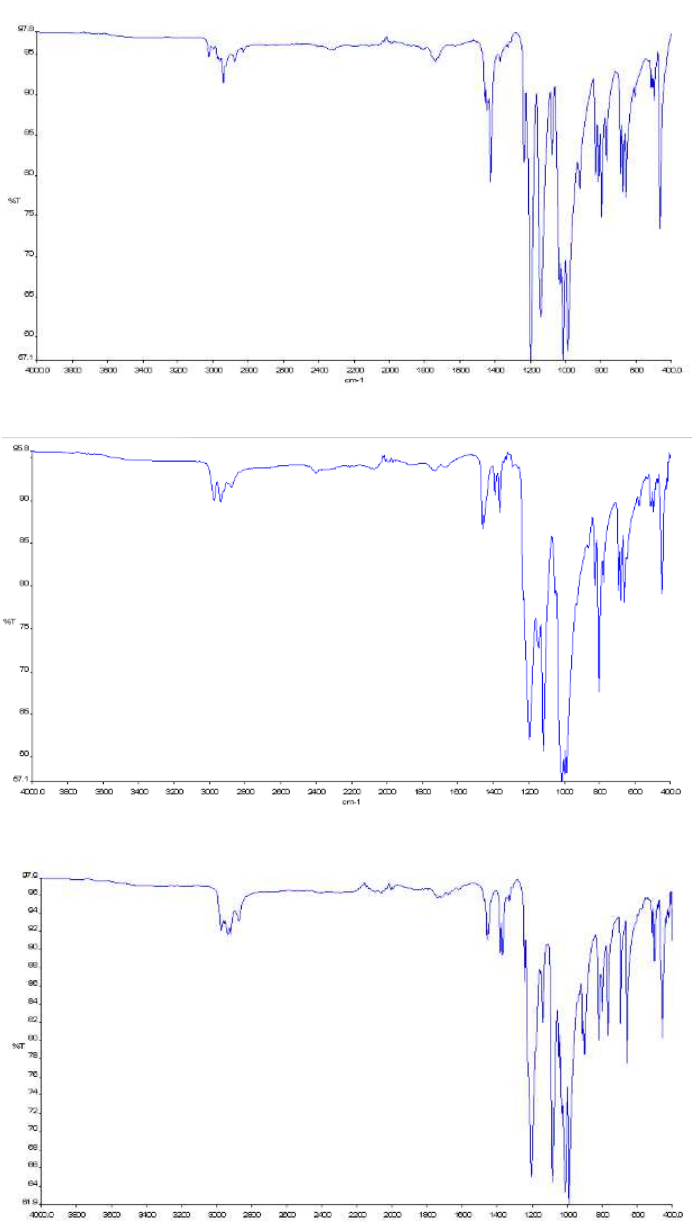
Figure S3. TGA (red trace) and DTA (blue trace) for (a) 1, (b) 2 and (c) 3.

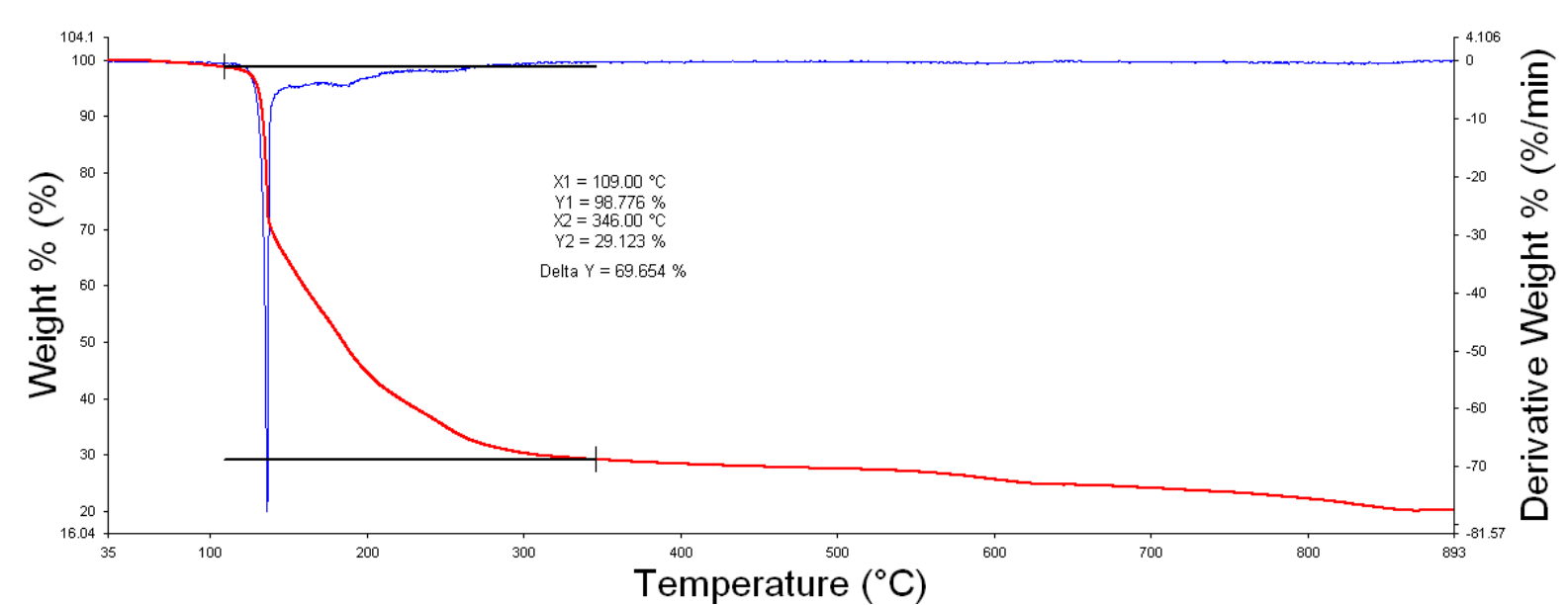

(a)

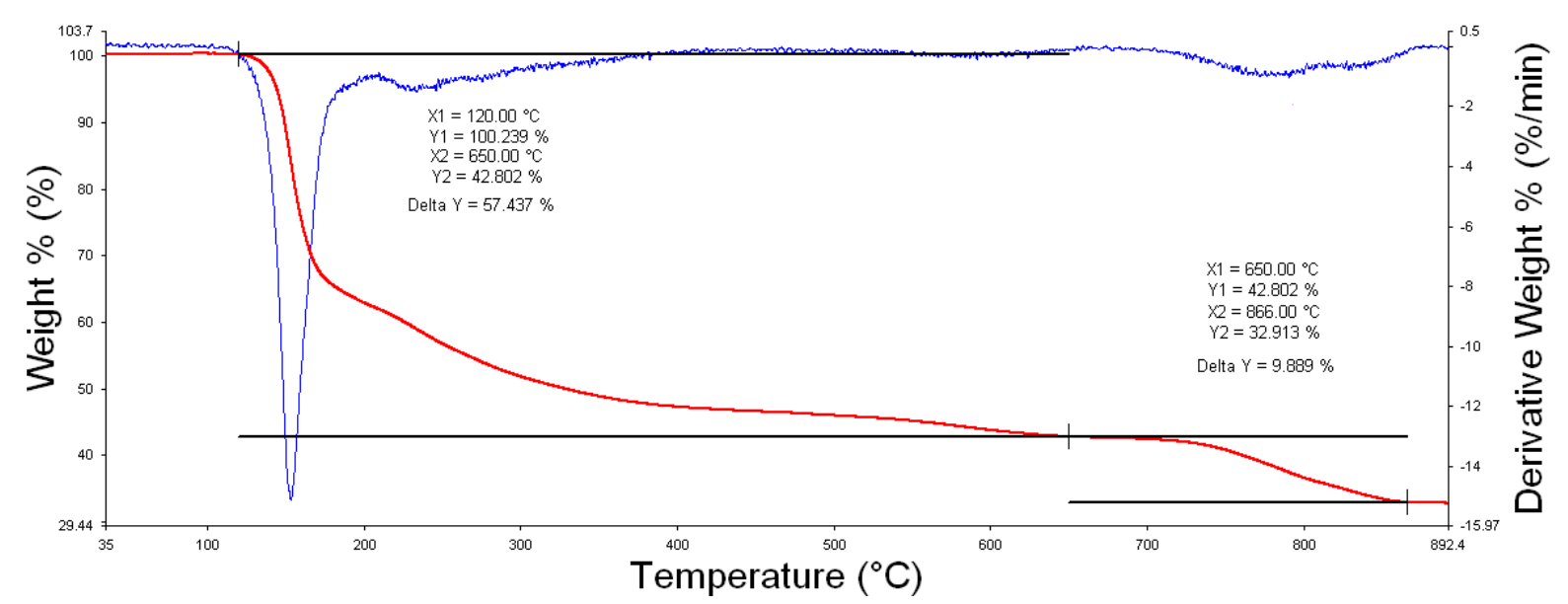

(b)

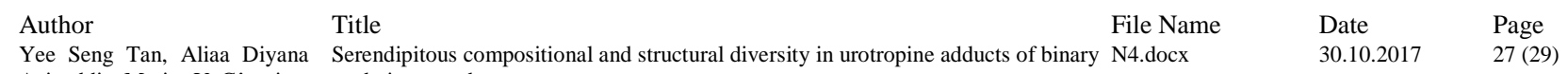
Azizuddin, Marius V. Câmpian, cadmium xanthates

A Edward R. 


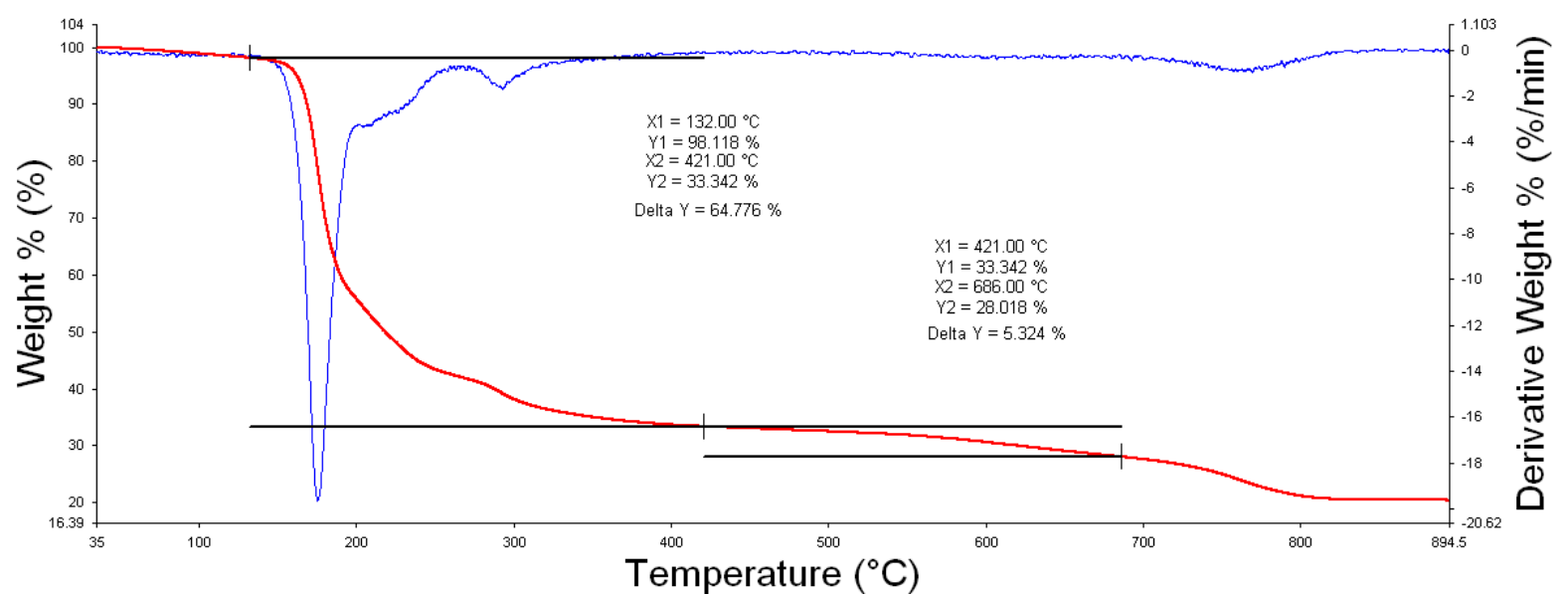

(c)

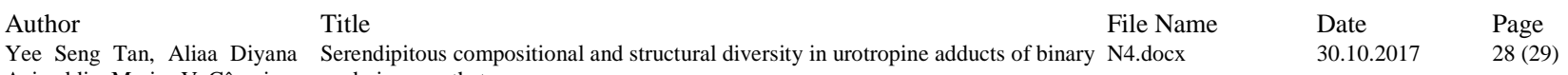
Azizuddin, Marius V. Câmpian, cadmium xanthates 
Figure S4. Solid-state emission spectra for 1-3: (a) $\lambda_{\mathrm{ex}}=295 \mathrm{~nm}$ and (b) $\lambda_{\mathrm{ex}}=360 \mathrm{~nm}$. The red spectrum corresponds to 1 (R $=\mathrm{Me}$ ), blue to 2 $(\mathrm{R}=\mathrm{Et})$ and green to $3(\mathrm{R}=\mathrm{iPr})$.

(a)

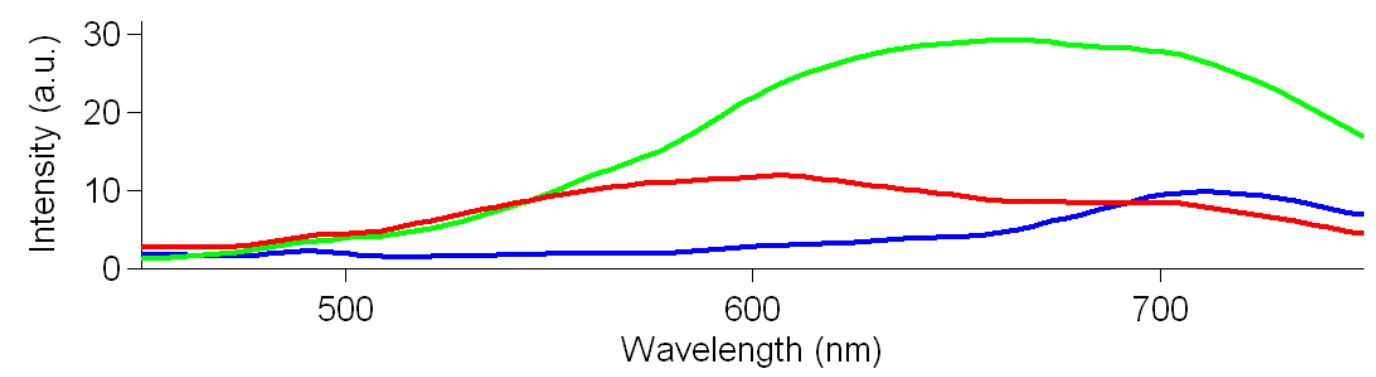

(b)

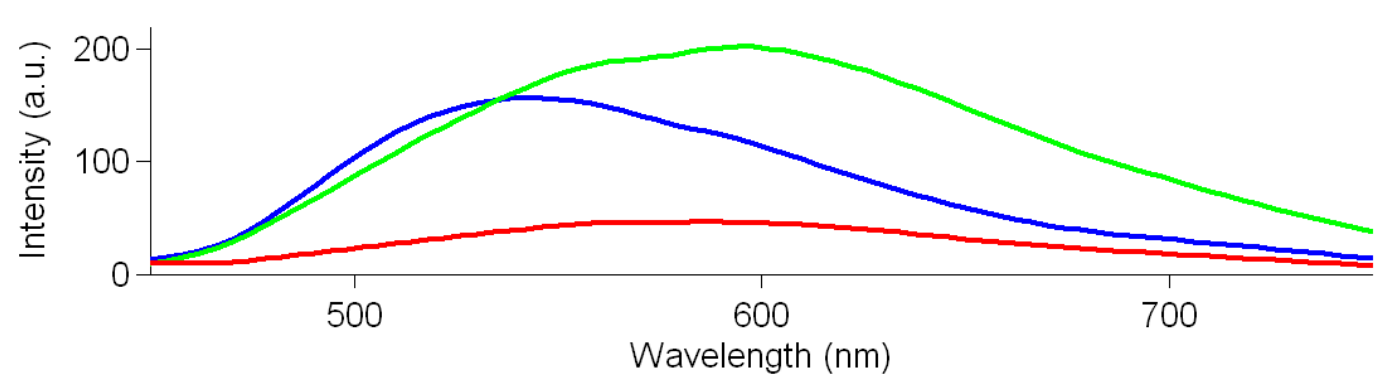

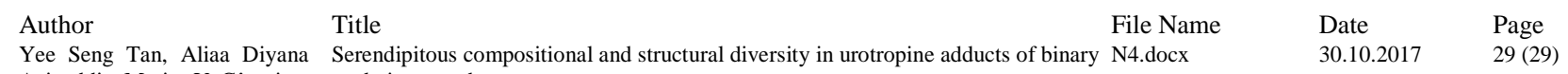
Azizuddin, Marius V. Câmpian, cadmium xanthates

Tiekink and Edwar 